\title{
UNIONS AS JURIDICAL PERSONS
}

Sir R. Reid [interrupting] : The trade unions are not corporations.

Prime Minister Balfour: I know; I am talking English, not law.

(House of Commons, 1904)1

IN industry, society and speech, unions are today regarded as entities no less "corporate" in character than business corporations." Notwithstanding basic differences in function and purpose, ${ }^{3}$ both unions and corporations typically act as institutional units distinct from their members or stockholders. ${ }^{4}$ Each enters as an entity into collective bargaining relationships with the other and into diverse economic relationships with third parties and its own members. ${ }^{5}$ Though seldom formally incorporated, ${ }^{6}$ a union is thus aptly

1. Quoted in Maitland, Moral Personality and Legal Personality, in Selecrer Essays 224 n.1 (1936).

2. See, e.g., United Mine Workers v. Coronado Coal Co., 259 U.S. 3H, 385 (1922) : “. . . in every way the union acts as a business entity, distinct from its members. No organized corporation has greater unity of action ...."; Witmer, Trade Union Liability: The Problem of the Unincorporated Corporation, 51 YALE L.J. 40-41, 63 (1941): "[W] have created an unincorporated corporation." See also RoBERTS, TRADE UNION GoverNMENT and Administration in Great Britain 3, 467 (1956) (hereinafter cited as ROBERTS).

3. See United States v. White, 322 U.S. 694, 697 (1944); Dodd, Some State Legislatures Go to War-on Labor Unions, 29 Iowa L. Rev. 148, 172-73 (1944). Compare statement of former CIO General Counsel: "Labor unions cannot be truthfully equated with corporations; their structures, their purposes, their method of operation are entirely different," zerith statement of General Counsel of United States Chamber of Commerce: "In many instances [unions] have become far more powerful than the employers with whom they do business. Today most observers would agree . . . 'the strongest unions . . . . are the most powerful economic organizations which the country has ever seen.' "Goldberg, AFL-CIO, in Proceedings of the Eighth Annual Mieeting, Industrial Relations Researce Ass'N 45, 46 (1956) ; Barton, Major Trends in American Trade Union Development, 1933-55, in id. 38, 39.

4. See United States v. White, 322 U.S. 694, 701-02 (1944); Superior Engraving Co. v. NLRB, 183 F.2d 783, 795 (7th Cir. 1950), cert. denied, 340 U.S. 930 (1951).

The text statement is not affected by the fact that in many instances members have greater control over union officials than stockholders over corporate management. Comparc Taft, The Structure and Government of Labor Unions (1954) and Roberts (considerable degree of control by union members), with BerLe \& MeANs, The ModerN Corporation and Private Property (1932) (stockholder of large corporation virtually powerless). But cf. Gilbert, Dividends and Demrocracy (1956) (optimistic view of possibilities for shareholder control).

5. See, e.g., Witmer, supra note 2 ; text at notes $162-71$ infra.

6. 2 Teller, Labor Disfutes and Collective Bargaining 179 (Supp. 1950) (hereinafter cited as TELLER). A statute permitting federal incorporation of unions was enacted in 1886 . Act of June 29,1886 , c. 567,24 STAT. 86 . Although introduced at the request of organized labor, 17 CoNG. Rec. 1900, 5565-66 (1886), it was repealed in 1932, Act of July 22, 1932, c. 524, 47 Srat. 741, because no bona fide union had ever incorporated under it. Some fraudulent insurance companies, calling themselves unions, had done so to avoid state regulation. S. Rep. No. 861, 72d Cong., 1st Sess. (1932) ; H. REp. No. 1763, 
called a "natural corporation." In law, however, the union's status has remained that of an unincorporated voluntary association like a social club or a church. ${ }^{\mathrm{s}}$ Despite its functional status as a corporate body, the union is not a "juridical person" or "legal entity" :9 a distinct right-and-duty bearing unit in the eyes of the law, like a natural person or corporation. The law regards a labor organization as an aggregate of individuals. ${ }^{10}$ The rights and duties

72d Cong., 1st Sess. (1932); 75 CoNv. Rec. 13997 (1932). Federal incorporation was again proposed in more recent Congresses. See Association of Westinghouse Employees v. Westinghouse Corp., 348 U.S. 437, 444 (1955).

Unions may incorporate under existing statutes in many states. See, e.g., N.Y. Mearberseip Corp. Law; Hagan v. Picard, 171 Misc. 475, 12 N.Y.S.2d 873 (Sup. Ct.), $a f f^{\prime} d, 258$ App. Div. 771, 14 N.Y.S.2d 706 (3d Dep't 1939). But compulsory state incorporation of unions has been held unconstitutional as a denial of freedom of speech, press and assembly. AFL v. Reilly, 113 Colo. 90, 95-96, 98-99, 155 P.2d 145, 147-49 (1944), 5S HaRv. L. Rev. 1256 (1945).

British trade unions may not incorporate under the Companies Act. Trade Union Act of $1871, \S 5,34 \& 35$ VICT., c. 31 .

The reluctance of trade unions to incorporate has been shared by voluntary associations in general. See Maitland, Trust and Corporation, in Selected Essays 141, 205-07 (1936).

7. Dicey, Law and Public Opinion in England 154 (1914). See also Maitland, Moral Personality and Legal Personality, in Selected Essays 223-25 (1936); Maitland's Introduction to GIeRKe, Political Theories of The MIDDLe Ages (1900); Laski, The Personality of Associations, 29 Harv. L. Rev. 404 (1916). But cf. Laski, Morris Cohen's Approach to Legal Philosophy, 15 U. CHr. L. Rev. 575 (1948); Duguit, Collective Acts as Distinguished from Contracts, 27 Y $\mathrm{ALE}$ L.J. 753 (1918).

8. See, generally, Lloyd, Unincorporated Associations (1938). The law governing internal affairs of unions is more assimilated to that of unincorporated associations than is the law concerning their external relationships. See 1 TELIER 291 (1940); LANDIS, CASEs on LABOR Law vii-viii (1934); RoBerts 34.

For a summary of union legal status in each American jurisdiction, see Forkosch, The Legal Status and Stability of Labor Organizations, 28 TEMr. L.Q. 1 (1954).

For a criticism of the dichotomy between unions' legal and functional status see $A$ Blow for Freedom, The Times (London), Nov. 8, 1955, p. 9, col. 2. See also 218 Law TIMrES 171, 172 (1954); Frankfurter, The Coronado Case, 31 New Republic 328, 330 (1922). But of. Bonsor v. Musicians' Union, [1956] A.C. 104, 136 (1955) (that union is entity in fact and common parlance is no ground to hold it entity in law).

9. Terms such as "juridical person," "juristic person," "legal entity," "legal person," "legal unit" are often used interchangeably. See Warren, Corporate Advantages Without InCORPORATION 14-15 (1929) (hereinafter cited as WARREN); cf. Bonsor v. Musicians' Union, [1956] A.C. 104, 107, 155 (1955). To avoid confusion, "juridical person" will be employed consistently herein. For a definition, see $i d$. at 134 . The term will be applied to unions in the same sense as in the statement "corporations are juridical persons," being synonymous with the use of "legal unit" by WARREN. The status or attributes characteristic of "juridical persons" will be referred to as "juridical personality." See also note 50 infra.

10. See, e.g., Tisa v. Potofsky, 90 F. Supp. 175, 180-81 (S.D.N.Y. 1950) ; Ex parte Edelstein, 30 F.2d 636, 638 (2d Cir.), cert. denied, 279 U.S. 851 (1929). To the law unions are "bodies unincorporate, bodies-the thought is charmingly English-which are bodiless." Laski, Personality of Associations, 29 HARv. L. REv. 404, 407 (1916). See also Tucker v. Eatough, 186 N.C. 505, 507, 120 S.E. 57, 59 (1923) (union like an "airy nothing"). 
ordinarily called "the union's" are in law those of its members. ${ }^{11}$ At common law, consequently, unions cannot sue or be sued without joining every member in the action. ${ }^{12}$ But like corporations, unions may acquire the procedural standing and substantive rights and duties of juridical persons through legislation. ${ }^{13}$

A developing recognition of the need to make unincorporated associations such as unions legally responsible led most jurisdictions to impose on them by statute various characteristics of juridical persons, particularly that of suability. ${ }^{14}$ As a practical matter, maintaining the common law rule would have prevented suit by or against these groups of increasing size and growing economic importance. ${ }^{15}$ For the most part, however, statutes affecting the status of unions dealt generally with unincorporated associations rather than with unions and their peculiar problems. ${ }^{16}$ In no American jurisdiction, moreover, are unions recognized as juridical persons for all purposes. ${ }^{17}$ Thus, unions

11. Comment, 32 Y ALE L.J. 59-61 (1922). Similarly, partners' legal rights and duties are called "the partnership's". See also WARREN 1-13.

12. United Mine Workers v. Coronado Coal Co., 259 U.S. 344, 385-86 (1922); 2 TelLer $\$ \$ 462,467$ (1940 \& Supps. 1947, 1950); Forkosch, The Legal Status and Suability of Labor Organizations, 28 TEMr. L.Q. 1, 2-5 (1954). However, the common law rule was often mitigated by such doctrines as waiver and estoppel. See sources cited above. See also Sturges, Unincorporated Associations as Parties to Actions, 33 Y ALE L.J. 383 (1924) ; Dodd, Dogma and Practice in the Law of Associations, 42 Harv. L. Rev. 977 (1929).

In equity the class suit device avoids the common law requirement for joinder of all members. United Mine Workers v. Coronado Coal Co., supra at 387; 2 TELLER $§ 462$ (Supp. 1950).

13. See Taff Vale Ry. v. Amalgamated Soc'y of Ry. Servants, [1901] A.C. 426, 429.

14. See note 16 infra.

Suability, though sometimes mistakenly equated with juridical personality, is but one of its characteristics. Puerto Rico v. Russell \& Co., 288 U.S. 476 (1933) ; Sperry Products, Inc. v. Association of American Railroads, 132 F.2d 408, 411 (2d Cir. 1942), cert. denied, 319 U.S. 744 (1943). See Forkosch, The Legal Status and Suability of Labor Organizations, 28 TEMP. L.Q. 1 (1954).

15. "To remand persons injured to a suit against each of the 400,000 members . . . would be to leave them remediless." United Mine Workers v. Coronado Coal Co., 259 U.S. 344, 389 (1922).

Union membership in the United States is approximately 18 million. See U.S. Bureau of Labor Statistics, Def't of Labor, Bull. No. 1185, Directory of National and INTERNATIONAL LABOR UNIONS IN THE UNITED States 1955, at 6-11. In the United Kingdom it is about $91 / 2$ million. RoBERTS app. 1. See also Barton, supra note 3, at 38-41 (growth in union economic power and financial resources); Comment, 65 YALE L.J. 369 n.1 (1956) (other associations); cf. Friedmann, Corporate Pozver, Government by Private Groups, and the Lawe, 57 COLuM. L. REv. 155 (1957).

16. The statutes are discussed in Forkosch, The Legal Status and Sutability of Labor Organizations, 28 TEגr. L.Q. 1 (1954). See also 2 TELLER $\$ \$ 465-66$ (Supp. 1950); S. Rep. No. 105, 80th Cong.,.1st Sess. $15-18$ (1947).

17. Forkosch, The Legal Status and Suability of Labor Organizations, 28 Temp. L.Q. 1 (1954). Even where for procedural purposes of suit an association is treated like a juridical person, it may be dealt with as an aggregate in other questions of adjective law, e.g., venue. Compare Sperry Products, Inc. v. Association of American Railroads, 
are treated differently from corporations in three major respects. Many procedural pitfalls still arise in suits involving unions, so that actions often fail on procedural grounds or are not brought at all. ${ }^{18}$ Secondly, even when procedural obstacles are overcome, the union may not be regarded as an entity in resolving the substantive issues presented. The "New York rule," for example, requires a showing that each member authorized or ratified an officer's act in order to bind the union; yet a corporation is bound by its agents acting within the scope of their employment. ${ }^{19}$ Finally, access to the federal courts on diversity grounds is available in cases involving unions only in the rare instance where every member is of diverse citizenship from the opposing party. ${ }^{20}$ But corporations can readily qualify for diversity jurisdiction since they are deemed citizens of the state of incorporation. ${ }^{21}$

These significant inadequacies can be remedied by full acceptance of unions as juridical persons. This Comment will first examine the basis in case and statute law for recognizing this status. It will then discuss the procedural, substantive, and diversity-jurisdiction consequences of such recognition, and the policy considerations they raise. ${ }^{22}$

\section{The Case Law and Statutory Basis for Juridical Personality}

American case law on union legal status has been closely related to English case law ${ }^{23}$ and both have depended heavily on questions of statutory interpretation. The early twentieth century House of Lords Taff Vale decision 24 provided the first important judicial impetus toward according unions status as legal persons. ${ }^{25}$ In 1922 the Supreme Court incorporated Taff Vale into

132 F.2d 408, 411 (2d Cir. 1942), cert. denied, 319 U.S. 744 (1943), with Juneau Spruce Corp. v. International Longshoremen's Union, 37 Cal. 2d 760, 235 P.2d 607 (1951). See Annot., 145 A.L.R. 700 (1943); Comment, 33 Calif. L. Rev. 444, 446 (1945).

18. See text at notes $143-61$ infra.

19. See text at notes 162-71 infra.

20. Class suits sometimes present an exception. See note 186 infra.

21. See text at notes 172-214 infra.

22. The suggestion to eliminate legal distinctions between incorporated and unincorporated bodies in general, see STEvens, Corporations $\$ 8$ (2d ed. 1949), will not be considered. Whatever the merits of this proposal, different and stronger legal and policy arguments relate to union status in particular. Even the classic attack against attributing juridical personality to unincorporated associations conceded that unions were the likeliest exception to this view. See WARREN 13.

23. Cf. Shulman, Book Review, 62 HARv. L. Rev. 1431 (1949).

On the legal status of British trade unions, see, generally, Citrine, Trade Union Law (1950); ROBERTS cc. I, II.

24. Taff Vale Ry. v. Amalgamated Soc'y of Ry. Servants, [1901] A.C. 426.

25. See Martin, Harold Laski 67 n. (1953); Maitland, The Unincorporated Body, in Selected Essays 128 (1936). The decision was largely responsible for the emergence of the British Labor Party. Attree, The Labour Party in Perspective and Twelve YeArs Later 45 (1949). The Party's political success secured passage of the Trade Disputes Act of 1906, 6 Evw. 7, c. 47, which barred the courts from entertaining tort suits against unions and so removed the practical effect of Taff Vale. See 2 BEER, A HISTORY 
American federal law in United Mine Workers v. Coronado Coal Co., ${ }^{26}$ and on the basis of Coronado later promulgated Federal Rule of Civil Procedure 17(b) governing suability of unincorporated associations. ${ }^{27}$ In the United States, moreover, subsequent statutory developments, notably the Wagner and Taft-Hartley laws, ${ }^{28}$ indicated legislative treatment of unions as legal units. In 1955 judicial recognition of union entity status achieved its furthest extension in the House of Lords' decision in Bonsor v. Musicians' Union, ${ }^{20}$ which reappraised the meaning of Taff Vale. Coming at a time when unionism is far better established than when Taff Vale and Coronado were decided, ${ }^{30}$ the reasoning of Bonsor calls for a similar reappraisal in American law. ${ }^{31}$ While none of this trio of decisions provides unambiguous authority on the legal status of unions, together with the American statutes they afford strong grounds for declaring unions juridical persons.

of British Soctalism 324-26 (1921). But the act left unimpaired the legal basis of the decision and its effect on juridical personality. Bonsor v. Musicians' Union, [1956] A.C. $104,125,139,154(1955)$.

26. 259 U.S. 344, 390-91 (1922). See text at note 65 infra.

27. FED. R. Civ. P. 17(b) reads:

".... In all other cases capacity to sue or be sued shall be determined by the law of the state in which the district court is held, except (1) that a partnership or other unincorporated association, which has no such capacity by the law of such state, may sue or be sued in its common name for the purpose of enforcing for or against it a substantive right existing under the Constitution or laws of the United States. ...."

See Advisory Committee Note on Rule 17(b), 3 Moore, Federal Practice 1303 (1948) (hereinafter cited as MOORE).

28. Wagner (National Labor Relations Act), 49 STAT. 449 (1935), as amended, 29 U.S.C. $\$ \$ 151-67$ (1952) ; Taft-Hartley (Labor Management Relations Act), 61 Stat. 136 (1947), 29 U.S.C. $\$ \$ 141-97$ (1952).

29. [1956] A.C. 104 (1955), reversing [1954] Ch. 479 (C.A.).

30. See note 15 supra. Union membership has increased roughly fivefold in the United States since Coronado and in Britain since Taff Vale. Probably even greater has been the increase in the power, resources and community acceptance of the respective labor movements. See Roberts 1; Saposs, Rebirth of the American Labor Movement, in ProCEEDINGS, op. cit. supra note 3 , at 16, 29.

Whatever the differences in motive behind them, Bonsor and the Taft-Hartley Act represent parallel developments in response to increased union strength; both recognize the need for legal safeguards of members' rights as well as changes in union legal status. See Taft-Hartley Act $\$ 1$ (b) ; RoBerTs 35-36; Forkosch, Internal Affairs of Unions, 18 U. CFr. L. REv. 729 (1951). Thus, an aggrieved member achieved essentially the same redress as in Bonsor by a Taft-Hartley unfair labor practice charge in Radio Officers Union, AFL v. NLRB, 347 U.S. 17 (1954). See note 165 infra.

31. On the need for a similar reappraisal of Canadian law on union status, see Trade Union Status in Canada, 6 CHITTX's L.J. 18 (1956). Since American "international" unions operate in Canada, uniformity of legal status in both countries is clearly desirable. It would avoid the anomalous situation in which an American union was held a legal entity when operating in Canada though not one at home. Vancouver Mach. Depot, Ltd. v. United Steelworkers, [1948] 2 West. Weekly R. (n.s.) 325, [1948] 4 D.L.R. 518 (B.C.C.A.). 


\section{Case Law: Bonsor, Taff Vale and Coronado}

In Bonsor a precedent that threatened to deny damages to a wrongfully expelled member of a union compelled the House of Lords' extensive consideration of a union's legal status. ${ }^{32}$ The trial court, affirmed by the Court of Appeal, ${ }^{33}$ declared that Bonsor's expulsion from his closed shop union was void as contrary to the union's rules. Interpreting the rules as a membership contract which impliedly provided that no member could be expelled otherwise than as stated, the court enjoined interference with his membership. But bound by a factually indistinguishable Court of Appeal precedent of 1915, Kelly's case, ${ }^{34}$ the court denied contract damages for lost wages. ${ }^{35}$ In Kelly the court had viewed a union as an aggregate of individuals, and therefore considered the membership contract an agreement of the members inter se. The union officials who wrongfully expelled plaintiff were deemed agents of every member including the plaintiff; thus the member could not recover for acts of his own agent. ${ }^{36}$

32. One commentator predicted that although legal theorists would discuss Bonsor for years to come, the decision's practical impact on English unions would be slight because wrongful expulsions are uncommon. Note, 72 L.Q. Rev. 3 (1956). But cases and other commentaries indicate the contrary. See National Amalgamated Stevedores Union v. Spring, Manchester Guardian, March 15, 1956, p. 5, cols. 1-2 (Liverpool Ch. Ct.) ; Bonsor v. Musicians' Union, [1954] Ch. 479, 506 (C.A.) ; Ex parte Malone, [1921.] 2 K.B. 694, 709; Thomas, Trade Unions and their Members, [1956] CanrB. L.J. 67; Grunfeld, Bonsor v. Musicians' Union, Socialist Commentary, Feb. 1956, p. 20.

33. Bonsor v. Musicians' Union, [1954] Ch. 479 (C.A.). The dissenting opinion contains the legal arguments accepted by the House of Lords and also a consideration of the policy questions which the House never discussed. The Court of Appeal considered the issue of such importance that it took the unusual step of recommending an appeal to the House of Lords. Id. at 506 .

On the law of wrongful expulsion prior to the House of Lords decision, see Thomas, Expulsion from Trade Unions, in THE LAw IN Action 45 (1954); Citrine, Trade Union LAw 211-25 (1950). On American law, see notes 165-66 infra.

34. Kelly v. National Soc'y of Operative Printers' Assistants, 84 L.J.K.B. 2236, 31 T.L.R. 632 (1915). Although counsel in Bonsor sought to distinguish $K e l l y$, see [1956] A.C. at 10 , none of the House of Lords found it distinguishable. Id. at $121,128,146-47$, $153,156$.

There was a Court of Appeal precedent apparently contrary to Kelly, National Union of General and Municipal Workers v. Gillian, [1946] K.B. 81 (C.A.), holding that a union suing for libel was a juridical person. But the Court of Appeal reconciled the cases by holding that a union's legal status was different vis-a-vis third parties than members. Bonsor v. Musicians' Union, [1954] Ch. 479,504 (C.A.). More plausible is the suggestion that the Court in Gillian ruled contrary to Kelly because the latter, not having been officially reported, was overlooked. Goodhart, The Legal Personality of a Trade Union, 70 L.Q. Rev. 322 (1954). In Bonsor neither Court of Appeal nor House of Lords nor reported arguments of counsel cited Willis and London Soc'y of Compositors v. B̈rooks, 62 T.L.R. 745, 746, [1947] 1 All E.R. 191, 192 (K.B. 1946), which in a dictum extended Gillian to authorize a member's suit against his union.

35. Bonsor v. Musicians' Union, [1956] A.C. 104, 105-06 (1955) (summarizing the trial court's opinion).

36. Id. at $121,131,147,153,157$. 
The House of Lords unanimously reversed the denial of damages to Bonsor but differed sharply on the question of juridicial personality. ${ }^{37}$ Two of the five Lords considered the union a juridical person, the membership contract being between it and each member. The agent breaching the contract had acted for the juridical person, not for any member, and the union was vicariously liable. ${ }^{38}$ Two other Lords approved Kelly's concept of the union as an aggregate of individuals, but overruled the holding that an agent could act on behalf of the very person injured. ${ }^{39}$ Although the union official was thus the agent of all other members and conceptually each must have been liable, ${ }^{40}$ no procedural device existed for executing judgment on any but common property because the suit was brought against the union in its registered name. ${ }^{41}$ This view would seem to call for allegation and proof of the liability of each present union member, an impracticable requirement in view of the change in membership since Bonsor's expulsion. ${ }^{42}$ These Lords, however, circumvented this logical obstacle by declaring that the "procedural consequences" of Taff Vale made the showing of individual liability unnecessary..$^{43}$ The fifth Lord adopted an intermediate position which, although somewhat ambivalent, seems to rest on a juridical person concept of unions. ${ }^{44}$ For him, unions resemble other unincorporated associations in not being conceptually distinct from their members at any instant, but they differ in the vital respect that "it is unnecessary to consider who were the members at any particular time." The union assumes "a collective responsibility for all members past, present and future, in respect of any cause of action for which it may be made liable. ..."45 Apparently, the member qua member cannot be individually liable. ${ }^{46}$ Rather, the union as an entity is a right-and-duty bearing unit: the

37. The case was remanded for assessment of damages. Following Bonsor, substantial damages were recovered by a wrongfully expelled member in Harkness v. Electrical Trades Union, Manchester Guardian, June 30, 1956, p. 4 (High Ct.).

38. [1956] A.C. at 120-32.

39. Id. at $132-49,155-58$.

40. See $i d$. at $148-49,157$.

41. Id. at $145-46,157$. Had the union been unregistered, it could not have been sued in its common name. Citrine, Trade Union LAW 145 (1950); see note 52 infra. The decision in Bonsor was limited to registered unions.

42. Bonsor v. Musicians' Union, [1956] A.C. 104, 118, 127 (1955). See also id. at 144-45.

43. Id. at 144-46, 155. The "procedural" interpretation is inconsistent with the concession that the union must be shown liable "as an organized combination." Id. at 145. See text at notes 137-47 infra; Lloyd, Damages for Wrongful Expulsion from a Tradc Union: Bonsor v. Musicians' Union, 19 MoDERN L. Rev. 121, 129 (1956). Moreover, Parliament's failure to provide for execution against union members would seem to imply that the legislature did regard the union as a juridical person. See also note $\mathbf{5 5}$ infra.

44. Since there is no "opinion of the court" in a House of Lords decision, commentators have disputed which position the majority did endorse. Compare Lloyd, supra note 43, and Field-Fisher, Trade Unions-No Longer Privileged?, 106 L.J. (n.s.) 454 (1956) with Thomas, Trade Unions and Their Members, [1956] CAMr. L.J. 67, and Notes, 72 L.Q. Rev. 3, 2 SyDNey L. Rev. 185 (1956).

45. [1956] A.C. at 149-50 (1955). (Emphasis added.)

46. Id. at $149-50,153$. 
official's act of expelling Bonsor bound neither Bonsor nor any other member, but only the unit. ${ }^{47}$ Irreconcilable with the aggregate theory, this position follows readily if unions are viewed as juridical persons. ${ }^{48}$ Even the concept that unions are not distinct from their members accords with one of the familiar theories of the nature of corporations. ${ }^{49}$

Despite their differing conclusions, the Lords all agreed that union status and juridical personality depended on the degree to which statutory provisions, explicit and implicit, had changed the common law. ${ }^{50}$ The statute on which the Bonsor rationale was based, the British Trade Union Act of $1871,{ }^{51}$ had removed the common law disabilities of unions and conferred minor privileges and responsibilities on those registering pursuant to the act. ${ }^{52}$ Taff Vale in

47. Id. at 153-54. The agent's act was equated with expulsion by a majority vote of the members. Just as "the union is bound by the voice of the majority," it is bound by the voice of union officials, though in both cases members individually are not bound by another's act. But cf. note 40 supra and accompanying text.

48. A comparison with the same Lord's opinion in the Scottish case of Mair v. Wood, [1948] Sess. Cas. 83, 88-93, supports the text position. There he was dealing with a partnership, which under Scots law is a juridical person. He regarded it, like the union in Bonsor, as formed by a membership contract inter se and as indistinguishable from its members at any given time. Moreover in his view the union, unlike the Scots partnership, is capable of sustaining vicarious liability to a member, and the members' liability is limited to their contributions to the common treasury. Thus the union resembles a corporation more closely than the partnership-juridical person. See also note 49 infra. This view is almost identical with the Supreme Court's in United States v. White, 322 U.S. 694, 701 (1944), that a union represents only the "common" not the "personal" interests of its members. See note 70 infra.

49. Cf. Stevens, Corporations 17, 46, 202 (1936); 1 Morawetz, Private CorporaTrons $\$ 1$ (2d ed. 1886); McGovney, A Supreme Court Fiction, 56 HARv. L. Rev. 853, 869 (1943); Daimler Co. v. Continental Tyre and Rubber Co., [1916] 2 A.C. 307, 316; Chisholm v. Georgia, 2 U.S. (2 Dall.) 419, 472 (1793).

If the union is a juridical person the only important difference resulting from considering the membership contract one inter se is that certain of its provisions may be made unenforceable by the restrictions on jurisdiction over "agreement[s] between members" in $\$ 4(1)$ of the British Trade Union Act. See Bonsor v. Musicians' Union, [1956] A.C. 104, 154 (1955); Amalgamated Soc'y of Carpenters v. Braithwaite, [1922] 2 A.C. 440; Thomas, Expulsion from Trade Unions, in The LAw IN Action 45, 52 (1954); Responsibilitics of Trade Unions, [1956] Scots L.T. 25, 30. But such unenforceability would not affect the union's status as a juridical person. Bonsor v. Musicians' Union, supra at 123; Taff Vale Ry. v. Amalgamated Soc'y of Ry. Servants, [1901] A.C. 426, 429, 431.

50. The conceptual basis of corporate personality was not discussed. The subject is one with which the Common Law has neither been particularly concerned nor consistent. See Duff, Personality in Roman Private law 206-21 (1938); Lloyd, Unincorporated Assoctations 1-17 (1938); Friedmann, Legal Theory c. 25 (3d ed. 1953); Maitland, Trust and Corporation, in Selected Essays 141. (1936).

Likewise, the proposals of this Comment do not depend on acceptance of any particular theory of the nature of corporate personality.

51. $34 \& 35$ VICT. c. 31 - called the unions' "charter of legal existence," Yorkshire Miners' Ass'n v. Howden, [1905] A.C. 256, 275, and "charter of incorporation," Amalgamated Soc'y of Ry. Servants v. Osborne, [1910] A.C. 87, 92 (1909). See Citrine, Trade UNION LAW pt. II (1950) (detailed consideration of statute).

52. E.g., unions were made exempt from common law rules on restraint of trade; 
1901 had held the act also necessarily implied, since no express provision to the contrary appeared, that the union-like a corporation-could be sued in its registered name and made liable to the extent of its funds for its agents' acts. $^{.53}$ In Bonsor the Lords disagreed on whether Taff Vale's interpretation of the statute decreed juridical personality for unions or only certain attributes of that status plus "procedural consequences" leading to the same result but on the theory that the members were being sued in a kind of representative action. ${ }^{54}$ The former interpretation of Taff Vale, it is maintained, is correct ${ }^{\text {to }}$

registered unions were given express power to hold property in the names of trustees, who might sue or be sued in respect thereto; remedies were provided against officers embezzling union funds; and the unions were obliged to file certain information and include certain provisions in their rules. Eight-ninths of union members belong to registered unions, but these have registered less because of resultant benefits than to conform to accepted standards. ROBERTS 18 . Cf. the important privileges conditioned upon registration under Taft-Hartley Act $\$$ 9(f) $-9(\mathrm{~h})$. See note 136 infra.

53. Taff Vale Ry. v. Amalgamated Soc'y of Ry. Servants, [1901] A.C. 426.

54. Both views were put forth in Taff Vale, but no choice between them was necessary to the decision and much of the language was ambiguous on the point. See Bonsor v. Musicians' Union, [1956] A.C. 104, 121-25, 129-31, 139-41, 150-51, 155 (1955). Cf. note 44 supra.

55. Four of the five opinions in Taff Vale voiced agreement with the trial court opinion of Farwell, J., [1901] A.C. 426-33, and Lord Shand, whose own position is least clear, expressly concurred in Farwell's "reasoning." Farwell quite clearly did not consider the suit a type of representative action, saying the closest analogy was a case like Ruck v. Williams, 3 H. \& N. 308, 157 Eng. Rep. 488 (Ex. 1858). The latter was an action for damages against unincorporated improvement commissioners, "a quasi corporate body" sued "in their quasi corporate character" and having no personal interest in the result. Id. at 319-20, 157 Eng. Rep. at 493. Nor could Ruck have been a representative action, since such actions did not exist at law until the Judicature Act of 1873. Likewise the argument in Taff Vale and Bonsor that Parliament intended the Trade Union Act of 1871 to provide an alternative type of representative suit seems to overlook the fact that such suits at law did not yet exist. Parliament would more likely have viewed the action as the already familiar suit against a corporate or quasi-corporate body.

Moreover, Farwell based his interpretation of the Trade Union Act on the construction of an act creating a corporation in Mersey Docks Trustees v. Gibbs, L.R. 1 H.L. 93 (1866), saying: "The proper rule of construction of statutes such as these is that in the absence of express contrary intention the Legislature intends that the creature of the statute shall have the same duties, and that its funds shall be subject to the same liabilities as the general law would impose on a private individual doing the same thing." Taff Vale Ry. v. Amalgamated Soc'y of Ry, Servants, [1901] A.C. 426, 430-31. (Emphasis added.) Thus for Farwell a trade union is a "creature of the statute" in the same sense as a corporation. He later called it a "statutory legal entity." Osborne v. Amalgamated Soc'y of Ry. Servants, [1909] 1 Ch. 163, 191 (1908).

Contemporary commentators likewise regarded Taff Vale as a suit against the union in a quasi-corporate rather than a representative character. See Cralmiers-Hunt, The Law Relating to Trade Unions 203-05 (1902); Erskine, Principles of the Law of Scotland 262 (20th ed., Rankine 1903).

The House of Lords decisions and dicta after Taff Vale, relied on in the various arguments in Bonsor, are not decisive either way. However, no citation is made of the seemingly persuasive Privy Council case from Canada (where the British Trade Union Act was substantially reenacted in 1872), White v. Kuzych, [1951] A.C. 585 (P.C.). 
and was adopted into American law in Coronado. ${ }^{\mathbf{5 6}}$ But most important is the unanimous recognition in Bonsor, as in Taff Vale, that unions are not inherently incapable of being juridical persons and that statutes conferring rights and duties on unions can, without express enactment but by necessary implication, make them juridical persons. The decision's chief signficance is thus its method of statutory construction. ${ }^{57}$ This approach may be similarly applied to relevant American statutes concerning unions.

The Supreme Court's Coronado decision should be interpreted as applying this method of statutory construction to make unions juridical persons as a matter of federal substantive law. ${ }^{58}$ Coronado is generally thought to have established the "merely procedural" rule that any unincorporated association may sue or be sued to enforce a federal substantive right. ${ }^{59}$ And federal rule 17 (b) is said to "codify" the decision. ${ }^{60}$ But as to unions, distinct from

There the by-laws provided that a member's acceptance of them was "a contract with this mion and with every other member therein." (Emphasis added.) The Judicial Committee of the Privy Council implicitly recognized the union rules constituted a contract between the member and the union as a distinct entity, since it unanimously reversed a wrongfully expelled member's judgment for damages because he had breached his contractual obligation to the union to exhaust internal remedies. It seems more than chance that the two Lords who in Bonsor held unions juridical persons, see text at note 38 stupra, had also sat on $K u z y c h$, while the other three had not. On the other hand, an argument against the juridical person interpretation of Taff Vale can be made from the fact that one of the judges who upheld the aggregate theory in Kelly (Swinfen-Eady, L.J.) is listed as counsel against the union in Taff Vale, [1901] A.C. at 434, and must have felt that his arguments there had not won the House's acceptance of the juridical person theory.

56. See text at notes 58-69 infra.

57. Lloyd, Danages for Wrongful Expulsion from a Trade Union: Bonsor $v$. Musicians' Union, 19 Modern L. Rev. 121, 128 (1956). See also Lloyd, Unincorporated Associations 161 (1938). Cf. London Ass'n v. Greenlands, Ltd., [1916] 2 A.C. 15, 38 (association not "creation of statute," hence not suable).

58. See 259 U.S. at 390-91.

Coronado, arising out of a violent strike, was a treble damage action under the Sherman Antitrust Act, 26 STAT. 209 (1890), 15 U.S.C. \$ 1 (1952). Suit was brought in Arkansas federal district court against the United Mine Workers international union and its officers, one area district of the UMW and its officers, 27 local unions in the district and their officers, and 65 individuals, most of whom were members of one of the unions. The unions appealed to the Supreme Court from a heavy damage judgment. They maintained that unincorporated labor unions could not be parties to an action or subject to a judgment. See id. at 346-50; WARREN 652-58. The unions lost on this point, although the judgment was reversed on other grounds. Not until after a second Supreme Court decision, 268 U.S. 295 (1925), and a fourth trial was the case finally settled for a small amount. See Lieberman, Unians Before the Bar 141-63 (1950).

59. E.g., Busby v. Electric Utilities Union, 323 U.S. 72, $76-77$ (Frankfurter, J., concurring) (1944), on renand, 147 F.2d 865, 867 (D.C. Cir. 1945) ; 3 Moore 1412 \& n.21 (1948) ; Clark, Code Pleading 203 (2d ed. 1947) ; Frankfurter, The Coronado Case, 31 New Repunlic 328, 329 (1922). But cf. Roberts, Labor Unions, Corporations-The Coranado Case, 5 ILL. L.Q. 200 (1923). See also note 67 infra.

60. See sources cited note 59 supra; note 27 supra. But cf. HART \& WECHSLER. ThE Federal Courts and the Federal Systear 965-66 (1953).

The argument of Frankfurter, J., in Busby, supra note 59, begs the question. In his 
other unincorporated associations, ${ }^{61}$ Coronado went much further. ${ }^{62}$ Although the union was sued under the Sherman Act, the Court's unanimous conclusion, that unions could be sued and held liable for acts of their agents, rested upon considerations independent of the act. ${ }^{63}$ This rule was not limited to cases

view, because the Court which incorporated Coronado into a rule of procedure lacked power to make substantive changes, Coronado must be procedural. The issue remains whether it is a misinterpretation of Coronado to call it "merely procedural." See note 67 infra.

61. See United States \& Cuban Allied Works Engineering Corp. v. Lloyds, 291 Fed. 889, 891-92 (S.D.N.Y. 1923) : "[Coronado] turned upon the character of a trade union as such. . . . It is to be read as applicable only to such cases."

62. The impression that Coronado applies to other unincorporated associations in the same manner as to unions stems from confusing the basic holding, limited to unions, with the alternative holding based on the Sherman Act and applicable also to other associations. See notes 63, 64, 69 infra. I.e., 3 Moore 1408-09 states: "In [Coronado] the Supreme Court held that an unincorporated labor union was suable as an entity, for the purpose of enforcing against it a federal stibstantive right, although the state court of the forum had earlier refused to recognize that it was so suable." (Emphasis altered.) From this interpretation of Coronado, rule $17(\mathrm{~b})$, see note 27 sutpra, readily follows and has equal application to all associations. But the italicized phrase, being the alternative holding, must be deleted to extract the broader holding applicable to unions in particular, which goes beyond $17(\mathrm{~b})$. This conflict between the broader holding and 17 (b) was called to the Supreme Court's attention by the District of Columbia Court of Appeals' Certificate, p.3, in Busby v. Electric Utilities Union, 323 U.S. 72 (1944). But the Supreme Court declined to answer the certified question. Id. at 72-77. Cf. National Ass'n of Industrial Ins. Agents v. CIO, 25 F. Supp. 540 (D.D.C. 1938) (Coronado makes union suable in D.C. although cause of action is non-federal).

Contemporary courts and commentators tended to take the broader view of Coronado. See 3 MOORE 1411; Annot., 27 A.L.R. 786, 789 (1923).

As applied to associations other than unions, e.g., Hansel v. Purnell, 1 F.2d 266 (6th Cir.), cert. denied, 266 U.S. 617 (1924), the broad view was unwarranted. As to them, Busby v. Electric Utilities Union, supra at 76 (concurring opinion), correctly said the scope of Coronado was authoritatively defined in Brown v. United States, 276 U.S. 134, 141 (1928) and Moffat Tunnel League v. United States, 289 U.S. 113, 118 (1933) (neither involve unions, both treat the Coronado alternative holding as the only one applicable). But neither these nor other Supreme Court cases have passed on the issue of whether the broad holding in Coronado is still valid as to unions. Dicta in United States v. White, 322 U.S. $694,703 \&$ n.5 (1944), seem to indicate that it is. See note 70 infra and accompanying text.

63. 259 U.S. at 383-91. The Court then briefly added that its conclusion was "confirmed in the case at bar" by specific provisions of the Sherman Act applicable to any "associations existing under or authorized by" federal or state laws. Id. at 392. (Emphasis added.) Undoubtedly, had the Court not wished to announce the broader rule, it could have rested the decision solely on the Sherman Act provisions, as the lower courts had done. See 235 Fed. 1, 6 (8th Cir. 1916), 258 Fed. 829, 837 (8th Cir. 1919). In fact that was what the Coronado Company's counsel asked, 259 U.S. at 364-67; see WARREN 660. But an amicus brief seeking the broader holding provided the arguments the Court accepted. Compare 259 U.S. at 376-81, with id. at 383-92; see note 66 infra. WARREN $661-65$, though advocating that the decision should have been based on the Sherman Act alone, concedes that it was not. See also Magill \& Magill, The Stability of Lahor Unions, 1 N.C.L. Rev. 81, 84-86 (1922) (holding not based on Sherman Act). But cf. LLoYv, UninCoRPoRated Associations 161-63 (1938) (holding based on Sherman Act). 
enforcing Sherman Act or other federal substantive rights. ${ }^{64}$ Rather the Court, speaking through Chief Justice Taft, reasoned by analogy from Taff Vale: federal statutes "recognizing" unions' existence were utilized as in the English decision to reach the same result on suability and liability. ${ }^{65}$ Other sources cited in the opinion also conceived of unions as juridical persons akin to corporations. ${ }^{68}$ Finally, suability of the union must have resulted from federal substantive law..$^{67}$ If suability were only procedural, state law, which if applic-

64. "[W]e think that [unions] are suable in the federal courts for their acts, and that funds accumulated to be expended in conducting strikes are subject to execution in suits for torts committed by such unions in strikes." 259 U.S. at 391 . Not only is this statement unrestricted to suits on federal substantive rights, but it clearly envisions suits for common law torts and other liability-creating "acts" involving no federal question. These presumably would be cognizable in federal courts under diversity jurisdiction. See text following note 172 infra.

65. 259 U.S. at $390-91$. The analogy is carefully drawn. See note 66 infra. See also Roberts, Labor Unions, Corporations-The Coronado Case, 5 ILL. L.Q. 200 (1923).

In addition to the reasoning of Taff Vale, Taft was plainly influenced as well by his observations of the nature of the union as a unified "business entity, distinct from its members," recognized as such by statutory and case-law developments. See 259 U.S. at 383-89; cf. Dodd, Dogma and Practice in the Laze of Associations, 42 HARv. L. REv. 977, $1003-06$ (1929). Taft's reasoning closely parallels that of an opinion in which he concurred as a circuit judge, Andrews Bros. Co. v. Youngstown Coke Co., 86 Fed. 585 (6th Cir. 1898). See note 182 infra.

In Coronado Taft apparently accepted the argument of union counsel that the union cannot be held unless it is a juridical person. 259 U.S. at 350, 352. But he found that its characteristics made it one. Cf. Puerto Rico v. Russell \& Co., 288 U.S. 476 (1933) (sociedad en comandita has all necessary characteristics of juridical person); Liverpool Ins. Co. v. Massachusetts, 77 U.S. (10 Wall.) 566 (1870) ; Morrison v. Standard Building Soc'y, [1932] A.D. 229 (Sup. Ct. South Africa); American Federation of Musicians v. Stein, 213 F.2d 679, 685 (6th Cir.), cert. denied, 348 U.S. 873 (1954) (union in Coronado had characteristics of juridical person). See also note 177 infra.

66. Aside from Taff Vale, Taft's analogy, 259 U.S. at 390, cited three sources interpreting Taff Vale : Hillenbrand v. Building Trade Council, 14 Ohio Dec. 628 (Super. Ct. 1904) ; Holland, Jurisprudence 341 (12th ed. 1916) ; Pollock, First Book on JurIsPRUDENCE 125 (2d ed. 1904). Whether Taff Vale actually premised union suability on the representative suit or juridical personality concept, see notes 54-55 supra and accompanying text, these sources make clear Taft adopted the latter into American law. All three were presented only in the amicus brief, arguing for juridical personality. 259 U.S. at 377,381 ; see note 63 supra. Hillenbrand, at $642-51$, seems a model for Taft's opinion. It moves from a description of the nature of trade unions, "having many of the characteristics of corporate bodies," to confirming their entity status by analogy of Ohio statutes to the British trade union acts. HoLland 341 points out the important differences between an aggregate of individuals and an "artificial person" such as a corporation or trade union. PozLock 125, also considering "artificial persons," likens the vicarious union liability of Taff Vale to that of a corporation. "Artificial person" is also the term Taft applied to unions in Coronado. 259 U.S. at 388, 390.

67. The misunderstanding of Coronado is due more than anything else to the phrase, often taken out of context, "the suability of trades unions ... is after all in essence and principle merely a procedural matter." 259 U.S. at 390 . (Emphasis added.) See, e.g., sources cited note 59 supra; Dodd, Dogma and Practice in the Law of Associations, $42 \mathrm{H}_{\text {ARv. }}$. L. Rev. 977, 1002 (1929). The subject of the full sentence is not "suability" but "such a conclusion as to suability," i.e., the conclusion of Taff Vale that the union was subject 
able in Coronado would have prohibited suability, would have governed under the Conformity Act. ${ }^{68}$ But Taft specifically stated the Conformity Act did not apply to suability of unions. ${ }^{69}$

\section{Statute Law: A Method of Construction}

The case for juridical personality of unions is further strengthened by subsequent enactment of labor legislation far more entensive than that existing when the Supreme Court decided Coronado. The Court recognized this in 1944 in United States $v$. White ${ }^{70}$ which held that a union's property was distinct

to suit and judgment as a quasi-corporate artificial person. The omitted part of the passage itself refers to "the existence of such powerful entities as trade unions." The portion of the opinion immediately following that passage suggests the "procedural matter" Taft had in mind. As a matter of substantive law, the union as an entity, and each member as an individual, incurred liability. The "procedural matter" was one of choosing which of the joint tortfeasors to proceed against. A plaintiff might, as in the Danbury Hatters' case, 208 U.S. 274 (1908), prefer redress against the individual members. See LTEBERMAN, UNIONS BEFORE THE BAR 58-59 (1950). But in a union of 400,000, such redress would be impossible. Taff Vale showed that statutes not explicitly conferring on unions power to sue and liability to be sued nevertheless did so by implication. American statutes do likewise. Thus the union alone could be sued, or as in Coronado, joined with some individual members as joint tortfeasors, and the "procedural" problem solved. Cf. Pirnie Simons \& Co. v. New York Stock Exchange, 89 N.Y.L.J. 189 (S.D.N.Y. 1933). Suability of the union is, in a sense, a "procedural" question, as it would be of a corporation, but the status from which suability derives is substantive.

Stevens, Corporatrons 42 n.72 (2d ed. 1949) states that if the judgment in Coronado could be satisfied only out of union assets, "then the decision must be regarded as changing the substantive law." Since the judgment was reversed on other grounds, the question was not explicitly resolved. But plaintiff's counsel acknowledged the judgment would not run against the members, 259 U.S. at 368 , and Taft gave no indication that judgment against the union could be executed other than on its funds. Id. at 391. In fact he implied just the opposite. Id. at 402-03. Moreover, it would be inconsistent to allow such a judgment against the union as an entity unless it enjoys juridical person status as a matter of federal substantive law. If it is an entity only for purposes of the Sherman Act suit, then under state law the union property remains that of the individual members, and there is no entity property on which to execute the federal judgment. See WARREN 666. Since Taft emphasized that execution would be levied on the common funds, he must have considered those funds property of the union-juridical person.

68. The Conformity Act of June 1, 1872, 17 STAт. 196. Subsequently replaced by the Federal Rules of Civil Procedure, the act provided that suits at law should conform "as near as may be" to state procedures in "like causes."

69. 259 U.S. at 391 . Taft, here again deliberately choosing the broad ground for decision, was referring to all suits in federal courts. He was not considering specific exceptions to the Conformity Act in a Sherman Act case, as was done in Pirnie Simons \& Co. v. New York Stock Exchange, 89 N.Y.L.J. 189 (S.D.N.Y. 1933). See also note 63 supra. Nor can it be said that the Conformity Act would have had no application to an antitrust suit, since one of the other issues in Coronado was decided on the basis of the Conformity Act. 259 U.S. at 382-83. And plaintiff's counsel were evidently under the impression they had brought the suit as a representative action in accord with Conformity Act procedures. WARREN 665-66.

70. 322 U.S. 694, 703 \& n.5 (1944). From Coronado and White, the Seventh Circuit observed: "It follows that the entity of the [union] is as much separate and apart from 
from that of its members and a union official therefore could not invoke the privilege against self-incrimination to withhold subpoenaed union records. White, moreover, was decided prior to enactment of the most comprehensive labor statute to date, the Taft-Hartley Act, which stressed the differentiation of union from members. ${ }^{71}$ American legislation now has much stronger implications of union juridical personality than the British statutes involved in Taff Vale $^{\mathbf{7 2}}$ and Bonsor. The latter were permissive, requiring no affirmative recognition or even toleration of unions by employers. ${ }^{73}$ But the Wagner Act, with the avowed purpose of encouraging the development of collective bargaining, ${ }^{74}$ affirmatively secured the right to organize unions and to compel employer recognition. ${ }^{75}$ If the theory is valid that corporations enjoy legal personality because the state has granted them a "concession" to exist, 76 it should apply even more so to unions, which experienced tremendous growth as a result of the act. ${ }^{77}$ Moreover, the language of the Wagner and TaftHartley Acts, unlike that of the British Trade Union Act, consistently treats a union as an entity rather than an aggregate. ${ }^{78}$ Predicated on the belief that the union's interest may often conflict with that of its members ${ }^{79}$ Taft-Hartley clearly deals with the union as distinct from its members. ${ }^{80}$ It specifically

the individual members as that of a corporation is from its stockholders." Superior Engraving Co. v. NLRB, 183 F.2d 783, 795 (7th Cir. 1950), cert. denied, 340 U.S. 930 (1951).

71. See, e.g., $\S \S 1$ (b), 301 (b). See also note 30 supra.

72. Cf. Pullman MIfg. Co. v. Local 2928, United Steelworkers, 152 F.2d 493, 499 (7th Cir. 1945) (dissenting opinion).

73. See Kahn-Freund, Legal Frameziork, in The Systear of Industrial Relations in Great Britain 42, 52-55 (Flanders \& Clegg ed., 1954).

74. Section 1. See also Norris-LaGuardia Act, $\$ 2,47$ STar. 70 (1932), 29 U.S.C. $\$ 102$ (1952) ; S. Rep. No. 105, 80th Cong., 1st Sess. 18 (1947) ; Cox, Labor Law 137 (3d ed. 1954); Dunlop, Collective Bargaining 17-18 (1949). The Taft-Hartley Act reiterated that collective bargaining was national policy, in reenacting $\$ 1$ of the Wagner Act and in $\S 201(a)$.

75. Sections $7,8,9$.

76. See, e.g., Stevens, Corporations $\$ 1$ (1936).

77. See Saposs, supra note 30, at 24; Melvin, The Use of Injunctions in Labor Disputcs, 36 A.B.A.J. 1007, 1058 (1950) ; Cox, LABor LAw 134 (3d ed. 1954) (increase from approximately 3 to 12 million union members in decade after 1933). The Wagner Act's predecessor, $\$ 7$ (a) of the N.I.R.A., 48 STAr. 195 (1933), also contributed to the growth. See Cox, op. cit. supra at 136-37.

Under the Wagner Act many employers were compelled by court order "to deal with a labor union in the manner contemplated by the Act. We know of none who has not regarded such union as a legal entity in a very real sense." Pullman Mfg. Co. v. Local 2928, United Steelworkers, 152 F.2d 493, 498 (7th Cir. 1945) (dissenting opinion). But cf. id. at 493-97.

78. E.g., compare $\$ \&$ of the Wagner Act as amended by Taft-Hartley and $\$ 301$ (b) of Taft-Hartley, with $\$ 4$ of the British Trade Union Act, 1871. See Bonsor v. Musicians' Union, [1956] A.C. 104, 135-39 (1955).

79. E.g., $\$ \$ 1(b), 8(b)(1),(2)$. See also note 30 supra.

80. "The Common Law concept of an unincorporated labor organization as a group of individuals having no separate entity apart from its members has been discarded 
provides in sections 301 and 303 for unions to sue and be sued by employers and other unions in connection with their most important activities: collective bargaining and economic coercion. ${ }^{81}$ Under section 301 (b) the union's collective liability replaces the several liability of its members. ${ }^{82}$ The members are given "all the advantages of limited liability without incorporation." 83

\section{The Method Applied: Section 301 of the Taft-Hartley Act}

An analysis of section 301 of the Taft-Hartley Act, 84 which governs suits involving unions, affords the clearest indication that unions should be recog-

-to the extent that it was not already outmoded in modern jurisprudence-by the Labor Management Relations Act, 1947. It is clear that the Act treats labor organizations, for all practical purposes, as juridical entities. See Sections $2(1)$ and 2(b) of the Act; also Title III ... Section 301."

International Longshoremen's Union, C.I.O., 79 N.L.R.B. 1487, 1507-08 \& n.40 (1948).

81. See note 84 infra.

82. See text at note 86 infra.

83. S. Rep. No. 105, 80th Cong., 1st Sess. 16 (1947).

84. "Section 301. (a) Suits for violation of contracts between an employer and a labor organization representing employees in an industry affecting commerce as defined in this Act, or between any such labor organizations, may be brought in any district court of the United States having jurisdiction of the parties, without respect to the amount in controversy or without regard to the citizenship of the parties.

"(b) Any labor organization which represents employees in an industry affecting commerce as defined in this Act and any employer whose activities affect commerce as defined in this Act shall be bound by the acts of its agents. Any such labor organization may sue or be sued as an entity and in behalf of the employees whom it represents in the courts of the United States. Any money judgment against a labor organization in a district court of the United States shall be enforceable only against the organization as an entity and against its assets, and shall not be enforceable against any individual member or his assets.

"(c) For the purposes of actions and proceedings by or against labor organizations in the district courts of the United States, district courts shall be deemed to have jurisdiction of a labor organization (1) in the district in which such organization maintains its principal office, or (2) in any district in which its duly authorized officers or agents are engaged in representing or acting for employee members.

"(d) The service of summons, subpoena, or other legal process of any court of the United States upon an officer or agent of a labor organization, in his capacity as such, shall constitute service upon the labor organization.

"(e) For the purposes of this section, in determining whether any person is acting as an "agent" of another person so as to make such other person responsible for his acts, the question of whether the specific acts performed were actually authorized or subsequently ratified shall not be controlling."

Section 303(a) provides that the commission of the same acts proscribed in $\S 8$ (b) (4) as union unfair labor practices shall be unlawful. Section 303(b) states:

"Whoever shall be injured in his business or property by reason [of] any violation of subsection (a) may sue therefore in any district court of the United States subject to the limitations and provisions of section 301 hereof without respect to the amount in controversy, or in any other court having jurisdiction of the parties, and shall recover the damages by him sustained and the cost of the suit." 
nized as juridical persons created by federal substantive law. Upon this recognition depend both the validity of important provisions of section 301 and, in view of the Supreme Court's interpretation in the Westinghouse case, ${ }^{85}$ the attainment of the aims sought by Congress in enacting the section. In particular, section 301 (b) must be considered either as itself contributing to juridical person status or as predicated on a tacit assumption that other legislation had created such status and section 301 merely declared some of its consequences. The result is the same under either view.

Although the range of legal situations in which section 301(b) applies remains unclear, all possible applications compel acceptance of the juridical person concept of unions. Section 301 (b) contains three separate provisions : unions are bound by the acts of their agents, they may sue or be sued as entities in federal courts, and money judgments obtained may be executed only against their assets, not those of members. ${ }^{86}$ The section may be construed in two ways. Its language is ostensibly of general applicability, and a sparse legislative history also suggests this interpretation. ${ }^{87}$ On the other hand, it has been contended that the section applies only to suits under sections 301 (a) and $303 .{ }^{38}$ Under either the general or restricted view of the section's applicability, its provisions taken together appear consistent only with a juridical person, not an aggregate, theory..$^{80}$

Under the restricted interpretation section $301(\mathrm{~b})$ applies in whatever suits may be brought under 301(a), although the nature of 301(a) suits is itself disputed. Section 301 (a) permits federal courts to entertain employer-union suits for violation of collective bargaining contracts, and also some (or possibly all $)^{00}$ suits between unions. By restricting the cause of action for violation of the bargaining agreement to employer and union and excluding individual employees, ${ }^{91}$ section 301 (a) treats the contract as one between two juridical

85. Association of Westinghouse Employees v. Westinghouse Corp., 348 U.S. 437 (1955).

86. See note 84 sutpra.

87. H.R. REP. No. 510, 80th Cong., 1st Sess. 66 (1947) ; Rock Drilling Union v. Mason \& Hanger Co., 90 F. Supp. 539, 542 (S.D.N.Y. 1950), aff'd, 217 F.2d 687, $691-92$ (2d Cir. 1954), cert. denied, 349 U.S. 915 (1955).

88. Forkosch, The Legal Status and Suability of Labor Organizations, 28 Temp. L.Q. 1, 6 (1954); Kaye \& Allen, The Suability of Unions, 1 LAB. L.J. 705, 706 (1950). See also Tisa v. Potofsky, 90 F. Supp. 175, 180 (S.D.N.Y. 1950).

89. Significantly, the one case cited by the Senate minority report to show $\S 301$ was unnecessary involved an incorporated union. S. REP. No. 105, 80th Cong., 1st Sess., pt. 2, at 13 (1947), citing Nederlandsch Amerikaanische Stoomvart Maatschappij v. Stevedores Benevolent Soc'y, 265 Fed. 397 (E.D. La. 1920).

90. See notes 114-16 infra and accompanying text.

91. Copra v. Suro, 236 F.2d 107, 113 (1st Cir. 1956); United Protective Workers v. Ford Motor Co., 194 F.2d 997 (7th Cir. 1952) ; Disanti v. Local 53, 126 F. Supp. 747 (W.D. Pa. 1954) ; Silverton v. Rich, 119 F. Supp. 434 (S.D. Cal. 1954) (collecting cases); Schatte v. International Alliance of Theatrical Stage Employees, 84 F. Supp. 669, 672 (S.D. Cal. 1949), aff'd, 182 F.2d 158 (9th Cir.), cert. denied, 340 U.S. 827 (1950); 2 Telupr 62, 175, 177 (Supp. 1950). See also Association of Westinghouse Employees v. Westinghouse Corp., 348 U.S. 437, 457-59, 464 (1955); note 115 infra. But cf. Kendall v. Pennsylvania R.R., 94 F. Supp. 875 (N.D. Ohio 1950) (railway union contract). 
persons. The Supreme Court in Westinghouse disagreed as to whether 301 (a) was solely a jurisdictional grant and the contract cause of action was still statecreated, 301 (a) merely providing a federal forum, or whether the section created a federal cause of action. ${ }^{92}$ Although a majority appears to have favored the former interpretation, ${ }^{93}$ some courts of appeals have continued to favor the latter. ${ }^{94}$ Because of these conflicting views, the effect of applying 301 (b) to both a state and a federally-created cause of action brought under 301 (a) will be examined.

If the 301(a) cause of action enforces state-created substantive rights to contract performance, 301(b)'s provisions undoubtedly require treatment of the union as a juridical person in such suits. State laws to the contrary will be disregarded, ${ }^{95}$ for it is not disputed that 301 was enacted precisely to nullify their effect.96 The crucial point is whether the 301(b) provisions may, as Justice Frankfurter thought in Westinghouse, be regarded as "procedural."17 Under Erie R.R. v. Tompkins ${ }^{98}$ the enforcement of state-created rights should be the same in a federal as in a state tribunal. Since 301 (b) was intended to be and is "outcome determinative," application of its provisions as "pro-

92. See Mendelsohn, Enforceability of Arbitration Agreements Under Taft-Hartlcy Section 301, 66 Y YLE L.J. 167 (1956) (hereinafter cited as Mendelsohn); Wollett \& Wellington, Federalism and Breach of the Labor Agreement, 7 Stan. L. REv. 445 (1955); Cox, Federalism in the Law of Labor Relations, 67 HARv. L. Rev. 1297 (1954).

93. See Mendelsohn 171; Wollett \& Wellington, supra note 92. 2 TELLER 46, 175 (Supp. 1950) supports the same interpretation.

94. See Signal-Stat Corp. v. Local 475, United Elec. Workers, 235 F.2d 298, 300 (2d Cir. 1956) ; Local 25, Teamsters Union, AFL v. W. L. Mead, Inc., 230 F.2d 576, 579-82 (1st Cir.), cert. disnissed, 352 U.S. 802 (1956); cf. Local 205, United Elec. Workers v. General Elec. Co., 233 F.2d 85, 94 (1st Cir.), cert. granted, 352 U.S. 822 (1956) ; International Ladies Garment Workers, AFL v. Jay-Ann Co., 228 F.2d 632 (5th Cir. 1956). See also Mendelsohn 171 n.16.

The uncertainties Westinghouse raised may soon be clarified by the Supreme Court, which has granted certiorari in three $\$ 301$ cases: Local 205, United Elec. Workers v. General Elec. Co., supra; Goodall-Sanford, Inc. v. United Textile Workers, AFL, 233 F.2d 104 (1st Cir.), cert. granted, 352 U.S. 822 (1956) ; Lincoln Mills v. Textile Workers Union, CIO, 230 F.2d 81 (5th Cir.), cert. granted, 352 U.S. 821 (1956).

95. E.g., Local 25, Teamsters Union, AFL v. W. L. Mead, Inc., 230 F.2d 576, 582 (1st Cir.), cert. dismissed, 352 U.S. 802 (1956); Shirley-Herman Co. v. International Hod Carriers Union, 182 F.2d 806, 809 (2d Cir. 1950); Schatte v. International Alliance of Theatrical Stage Employees, 84 F. Supp. 669, 672-3, (S.D. Cal. 1949), aff'd, 182 F.2d 158 (9th Cir.), cert. denied, 340 U.S. 827 (1950).

96. See, e.g., S. REP. No. 105, 80th Cong., 1st Sess. 15-18 (1947) ; 2 TeLLER 179 (Supp. 1950) ; Association of Westinghouse Employees v. Westinghouse Corp., 348 U.S. 437, 446-49 (1955).

97. Id. at 443, 449. Accord: Wollett \& Wellington, supra note 92, at 473. See also Cox, Some Aspects of the Labor Management Relations Act, 1947, 61 HARv. L. REv. 274, 303-05 (1948).

However, Justice Frankfurter's statement in Westinghouse, 348 U.S. at 444, that English courts would likewise interpret the statute procedurally, is refuted by the substantive interpretation given to weaker legislative language in Bonsor.

98. 304 U.S. 64 (1938).

99. See Guaranty Trust Co. v. York, 326 U.S. 99, 109 (1945) (rule substantially affecting result of litigation is "outcome-determinative" for Erie purposes). 
cedural" rules would violate the Erie principle. ${ }^{100}$ And where state law denies the union's capacity to sue or be sued, the "procedural" view of 301 (b) would also violate the rule derived from Angel v. Bullington: that a party lacking ca-

100. Eric itself was a diversity case. However, under Justice Frankfurter's view of $\S$ 301, "Congress merely furnished a federal forum for enforcing the body of contract law which the States provide. . ." 348 U.S. at $442,443-49$. State courts apparently retain concurrent jurisdiction. Thus, although the parties are not necessarily of diverse citizenship, a federal court's role in $\S 301$ jurisdiction seems indistinguishable from its function when exercising concurrent jurisdiction to enforce state law in diversity cases. In diversity, the Supreme Court has held the federal court to be in substance "only another court of the state"; hence Erie bars it from applying "outcome determinative" federal rules of procedure. Guaranty Trust Co. v. York, 326 U.S. 99, 108-09 (1945); Bernhardt v. Polygraphic Co., 350 U.S. 198, 203 (1956). Accordingly, under Justice Frankfurter's view that "all it [\$ 301] does is to give procedural directions to the federal courts," 348 U.S. at 443, those directions, when "outcome determinative," likewise should be barred by Erie. Cf. Hamilton Foundry \& Mach. Co. v. International Molders Union, 193 F.2d 209, 215 (6th Cir. 1951), cert. denied, 343 U.S. 966 (1952) (outcome-determinative state law held to apply even on assumption that $\$ 301$ rights were federally-created). But see Local 205, United Elec. Workers v. General Elec. Co., 233 F.2d 85, 95 (1st Cir.), cert. granted, 352 U.S. $\$ 22$ (1956) ( 301 suit distinguished from diversity suit).

The extent to which Erie applies to enforcement of state law in federal nondiversity cases is not yet clearly defined. Hill, State Procedural Law in Federal Nondiversity Litigation, 69 HARv. L. Rev. 66, 67 (1955). Courts have recognized Erie's applicability in some nondiversity situations. See Hill, The Erie Doctrine in Bankruptcy, 66 HARv. L. Rev. 1013, 1034 (1953) ; Clark, State Law in the Federal Coutrts: The Brooding Omnipresence of Erie v. Tompkins, 55 Yale L.J. 267, 280-81 (1946); HART \& WeCHSLER, The Feneral Courts and the Federal Systear 697 (1953). Guaranty Trust, supra at 101, divided cases for Eric purposes into only two categories: those "adjudicating a claim based on a federal law," and those where "rights and obligations are created by one of the States, and for the assertion of which, in case of diversity of the citizenship of the parties, Congress has made a federal court another available forum." (Emphasis added.) Section 301 cases on state-created rights are clearly in the latter category. The italicized phrase simply states the condition, as to the character of the parties, that Congress attached for access to the alternative forum. Where Congress' condition is instead that the character of the parties be union and employer, the rest of the statement should not be affected.

Erie rests on three bases: a strong policy against forum-shopping, an interpretation of the Rules of Decision Act (28 U.S.C. § 1652 (1952)), and a constitutional requirement compelling that interpretation to avoid infringement of state judicial power. See 304 U.S. at 74-80. All three seem applicable to $\$ 301$ cases if $\S 301$ (a) creates no federal rights and $\S 301(\mathrm{~b})$ is "merely procedural." The anti-forum-shopping policy has been most emplasized in the Supreme Court's post-Erie decisions. See, e.g., Guaranty Trust, supra; Bernhardt, stpra; Hart, The Relations Between State and Federal Law, 54 Colum. L. REv. 489, 512-13 (1954). Although this policy applies in diversity to the nonresident forum-shopper, it is even more applicable when the forum-shopper need not be a nonresident. Otherwise, where concurrent $\$ 301$ and state-court jurisdiction exist, a resident plaintiff could freely choose his court and his result. And a nonresident plaintiff could, by invoking jurisdiction under $\S 301$ instead of diversity, evade Erie's restrictions.

The Rules of Decision Act is applicable in nondiversity cases. E.g., Chattanooga Foundry and Pipe Works v. Atlanta, 203 U.S. 390, 397 (1906) ; Hill, The Erie Doctrine in Bankruptcy, 66 HaRv. L. REv. 1013, 1034-35 (1953).

The constitutional basis of Erie long remained uncertain. See id. at 1031-33. But in 
pacity in a state's courts cannot be given capacity to enforce a non-federal right in federal courts in that state. ${ }^{101}$ But if 301 (b) is itself "substantive" law, any objections based on Erie and Angel disappear, for under the supremacy clause of the Constitution federal substantive law supersedes conflicting state provisions. ${ }^{102}$ The union's situation is analogous to that of a federally-created corporation sued on a state-created contract cause of action. ${ }^{103}$ Federal substantive law determines that the corporation has capacity to be sued, ${ }^{104}$ that judgment may not be executed against the stockholders' personal assets, and that the corporation may be bound by its agents. State substantive law determines whether the agent validly bound the corporation, whether the contract was breached, and the measure of damages. The corporation's case would be cognizable in the federal district court if Congress had made a special grant of federal jurisdiction, like 301 (a) ; otherwise only the state courts could entertain the action. ${ }^{105}$ But the foregoing "substantive" rules would apply equally in. either instance.

1956 it was reaffirmed in Bernhardt, supra. The case held the United States Arbitration Act inapplicable to diversity cases not involving interstate commerce to avoid probably unconstitutional infringement of state powers by the "outcome determinative" federal enforcement of arbitration. See The Supreme Court, 1955 Term, 70 HaRv. L. Rev. 83, 13741 (1956). The constitutional doubts would seem equally strong in applying the "outcome determinative" rules of $\S 301$ (b) if $\S 301$ is merely procedural. In Wilson \& Co. v. United Packinghouse Workers, 83 F. Supp. 162, 166 (S.D.N.Y. 1949), the constitutionality of $\S 301$ (b) was sustained as not invading state powers only by holding that $\$ 301$ (a) created a federal substantive right, so that federal procedures applied to its enforcement.

101. Angel v. Bullington, 330 U.S. 183 (1947) ; Woods v. Interstate Realty Co., 337 U.S. 535 (1949).

Moore, Commentary on the Judicial. Code 318 (1949) points out that Angel qualifies rule 17 (b) insofar as the latter implies a party may have capacity to sue on statecreated rights in federal courts despite the forum state's law. Angel must similarly qualify $\S 301$ (b) if that section be considered an amendment to Rule 17(b), as it was in Rock Drilling Union v. Mason \& Hanger Co., 90 F. Supp. 539, 542 (S.D.N.Y. 1950), aff'd, 217 F.2d 687, 691 (2d Cir. 1954), cert. denied, 349 U.S. 915 (1955), and apparently in Justice Frankfurter's Westinghouse opinion that $\$ 301$ merely gave "procedural directions to the federal courts."

102. U.S. Const. art. VI, cl. 2. See Shirley-Herman Co. v. International Hod Carriers Union, 182 F.2d 806, 809 (2d Cir. 1950); Pullman Standard Car Mfg. Co. v. Local 2928, United Steelworkers, 152 F.2d 493, 497-99 (7th Cir. 1945) (dissenting opinion). The application of the supremacy clause has been particularly extended in the labor field. Thus, even a "private agreement" made pursuant to federal law has been held to supersede state law. Railway Employes' Dep't AFL v. Hanson, 351 U.S. 225, 232 (1956).

103. See International Ladies Garment Workers, AFL v. Jay-Ann Co., 228 F.2d 632 (5th Cir. 1956) (union likened to federally-created corporation suing on state-created right). Cf. Osborn v. Bank of the United States, 22 U.S. (9 Wheat.) 737, 823-28 (1824). Unions were frequently likened to corporations in the congressional debate on $\$ 301$. E.g., 93 CoNG. REc. 3839, 6521 (1947).

104. In some cases capacity may be implied without express statutory direction. See 3 MOORE 1403.

105. See cases cited note 103 supra. According to Jay-Ann, however, $\$ 301$ (a) was not a grant of federal jurisdiction absent the normal federal question. 228 F.2d at 634 . 28 U.S.C. $\$ 1349$ bars federal jurisdiction based merely on grounds of federal incorporation. 
Alternatively, if section 301 (a) creates a federal substantive right to contract performance, all the foregoing questions would be decided as matters of federal law. Although affixing a "procedural" label to $301(\mathrm{~b})$ 's provisions in this context would not raise questions as to their validity, ${ }^{106}$ it would nevertheless be inaccurate. The determination and incidence of liability for breach of contract would still depend on the 301 (b) rules. ${ }^{107}$ In their absence the Norris-La Guardia rule would apply: that an agent's authorization or ratification must be proved to bind the union. ${ }^{108}$ And under Federal Rule of Civil Procedure 69 judgment could be executed on members' personal assets where state law so allowed. ${ }^{109}$ Moreover, if 301 (a) creates a federal substantive right, it may well pre-empt state law on collective bargaining contracts. ${ }^{110}$ Thus the section 301 concept that the union enters a collective bargaining relationship as a juridical person would pro tanto supersede state denial of union juridical personality. ${ }^{111}$

Congress was apparently concerned not with whether state or federal contract law would apply, but with overcoming the barriers to contract enforce-

See also Association of Westinghouse Employees v. Westinghouse Corp., 348 U.S. 437, 450-51 (1955).

106. Shirley-Herman Co. v. International Hod Carriers Union, 182 F.2d 806, 809 (2d Cir. 1950); Wilson \& Co. v. United Packinghouse Workers, 83 F. Supp. 162, 166 (S.D.N.Y. 1949) ; cf. Local 25, Teamsters Union, AFL v. W. L. Mead Inc., 230 F.2d 576, 582 (1st Cir.), cert. dismissed, 352 U.S. 802 (1956).

107. See Association of Westinghouse Employees v. Westinghouse Corp., 348 U.S. 437, 451 (1955).

108. Norris-LaGuardia Act, $\$ 6,47$ STAт. 71 (1932), 29 U.S.C. $\$ 106$ (1952); United Brotherhood of Carpenters v. United States, 330 U.S. 395, 401-03 (1947). See United Mine Workers v. Patton, 211 F.2d 742, 746-48 (4th Cir.), cert. denied, 348 U.S. 824 (1954).

109. E.g., in South Carolina judgment against the union may be executed on the personal property of members not served. S.C. CoDE $\$ 10-1516$ (Supp. 1955); see Hall v. Waiters, 226 S.C. 430, 85 S.E.2d 729 (1955). The South Carolina statute might be deemed to deprive unserved parties of property without due process of law. But the provision probably could be upheld by analogy to Operative Plasterers' Ass'n v. Case, 93 F.2d 56 (D.C. Cir. 1937) (default judgment against union did not violate due process where service had been made on member who could reasonably be expected to give notice to union); see also 3 Moore 1408 n.5.

Federal rule 71 also contemplates enforcement of court orders against parties not served.

For cases applying local law under rule 69, see Juneau Spruce Corp. v. International Longshoremen's Union, 128 F. Supp. 697, 705-06, 131 F. Supp. 866 (D. Hawaii 1955); 7 MOORE 2418-19.

110. See Mendelsohn 187-90.

111. The federal right might also be enforceable by or against the union as an entity in state courts. Cf. Williams v. United Mine Workers, $294 \mathrm{Ky} .520,172$ S.W.2d 202 (1943). But cf. Bunch v. Launius, 222 Ark. 760, 262 S.W.2d 461 (1953).

Similarly, \& 303 creates federal substantive rights pre-empting state law. Section 303 (b) expressly allows these to be enforced in state courts, though without express requirement that the liability-limiting, entity and agency provisions of $\S 301(\mathrm{~b})$ be followed. See note 84 supra. It is unlikely Congress intended all these $\$ 301$ (b) provisions to be circumvented in allowing $\$ 303$ actions to be brought in state instead of federal 
ability resulting from state nonrecognition of union juridical personality. ${ }^{112}$ Accordingly the view that 301 creates a federal substantive right to performance of collective bargaining contracts would be consistent with its intent. ${ }^{113}$ It is difficult, however, to conceive what possible federal substantive right Congress could have meant to create by the parallel 301(a) provision for suits between unions. ${ }^{114}$ It is not even clear whether such suits are limited to "contract" actions ;15 nor is any legislative history found showing what contracts Congress imagined unions make with each other. ${ }^{110}$ Congress apparently meant

court. This further supports the implication that Congress considered unions entities created by federal substantive law, causing provisions like those of $\S 301(\mathrm{~b})$ to bind state courts without need for re-expression in $\S 303$. Cf. International Longshoremen's Union v. Juneau Spruce Corp., 342 U.S. 237, 242-43 (1952). But see Bunch v. Launius, supra.

112. See Association of Westinghouse Employees v. Westinghouse Corp., 348 U.S. 437, 444-49 (1955) ; S. Rep. No. 105, 80th Cong., 1st Sess. 15-18 (1947) ; H.R. Rep. No. 245, 80th Cong., 1st Sess., $45-46$ (1947) ; H.R. Rep. No. 510, 80th Cong., 1st Sess. 65 (1947) ; Cox, Some Aspects of the Labor Management Relations Act, 1947, $61 \mathrm{H}_{\mathrm{ARv}} \mathrm{L}$. REv. 274, 303-05 (1948).

113. See Association of Westinghouse Employees v. Westinghouse Corp., 348 U.S. 437, 465 (1955) (dissenting opinion); Note, 57 Y ALE L.J. 630 (1948); of. Mendelsohn 183-84 (the legislative intent cannot be clearly ascertained from the legislative history).

114. Section 301 (a) encompasses "Suits for violation of contracts between an employer and a labor organization . . or between any such labor organizations . . ." (Emphasis added.) See note 84 supra.

115. There was considerable controversy as to whether "between an employer and a labor organization" modified "suits" or "contracts," but the former interpretation prevailed. See Mendelsohn 195 n.115; note 91 supra. Accordingly the second "between" clause-"between any such labor organizations"-should likewise be taken to modify "suits," and "for violation of contracts" limited to the employer-union provision in which it appears. Thus $\S 301$ (a) would be read: "suits for violation of contracts between an employer and a labor organization ... or [suits] between any such labor organizations, may be brought in any district court of the United States. . ." Since Congress evinced great concern with the difficulties of suing unions, see note 112 supra and accompanying text, but none with failure of unions to honor contractual agreements among themselves, this reading seems most plausible. The "contracts" with which Congress was concerned were solely union-employer collective bargaining contracts. See, e.g., S. REP. No. 105, 80th Cong., 1st Sess. 15-18 (1947). However, Congress was concerned with inter-union jurisdictional disputes, as evinced by its passage of $\S \S 8(\mathrm{~b})(4)(D)$ and $303(\mathrm{a})(4)$ of the act. It was suggested that under $\$ 301$ a declaratory judgment should be available to resolve jurisdictional disputes, see 93 CoNG. REc. 3656-57 (1947); this may have been a reason for the Conference Committee's decision to add to $\S 301$ the provision for suits between unions. See note 116 infra. But as such disputes are not generally over violations of contracts between the competing unions, it would follow that $\S 301$ (a) jurisdiction over inter-union suits was not intended to be limited to suits "for violation of contracts."

116. The $\S 301$ (a) provision for suits between unions did not appear in the original version of either the House or Senate Bill. It was added by the Conference Committee, but their report makes no reference to the reasons for its addition. See H.R. REP. No. 510, 80th Cong., 1st Sess. 65 (1947). The only reference to the addition was Senator Taft's cryptic statement that the Conference Committee report differed from the Senate bill in providing "that suits for violation of contracts between labor organizations, as well as between a labor organization and an employer, may be brought in the Federal courts." 
state substantive law to apply in these inter-union 301(a) suits, even if federal substantive law applies in 301(a) suits on collective bargaining contracts. ${ }^{117}$ Hence 301 (b) must be intended to govern in some suits on state-created rights, even if 301 (b) is limited to 301 (a) and 303 suits. ${ }^{118}$ The argument based on Erie and Angel, discussed above, consequently requires the substantive in-' terpretation of 301 (b). In addition, if the 301 (a) jurisdictional grant is deemed

93 Conc. REc 6445 (1947). But there was no elaboration or discussion of what the interunion contracts were. And Senator Taft's thought that "between any such labor organizations" in $\$ 301$ (a) modified "contracts" rather than "suits" is merely a repetition of his view that the first "between" clause did likewise. But the courts have rejected the latter view. See notes 91 and 115 supra. Moreover, Taft's general philosophy that a union should be suable and liable for the acts of its agents in the same manner as a corporation is equally applicable to inter-union disputes. See 93 CoNG. Rec. 3839, 6521 (1947).

There has been little litigation to clarify the suits between unions provision. Snoots v. Vejlupek, 87 F. Supp. 503 (N.D. Ohio 1949), Kriss v. White, 87 F. Supp. 734 (N.D.N.Y. 1949), and Sun Shipbuilding Co. v. Industrial Union, 95 F. Supp. 50, 53 (E.D. Pa. 1950), seem correct in holding the provision inapplicable to intra-union disputes, although these may involve violations of contractual obligations under union constitutions and rules. But these intra-union cases give no reason for limiting inter-union $\S 301$ suits to contract actions. Schatte v. International Alliance of Theatrical Stage Employees, 84 F. Supp. 669, 672 (S.D. Cal. 1949), aff'd, 182 F.2d 158 (9th Cir.), cert. denied, 340 U.S. 827 (1950), did involve an inter-union dispute. It correctly held that a $\S 301$ suit could not be maintained because not brought in the union's name; but the dictum that an inter-union $\S 301$ suit must be for "violation of a labor contract . . . between labor organizations" is unelucidated and unsupported. Copra v. Suro, 236 F.2d 107, 113 (1st Cir. 1956), relied solely on Senator Taft's remark, supra, in holding the second "between" modified "contracts," not "suits," although the first "between" modified "suits." However, the latter case, supra at 114-15, also made the interesting suggestion that unions may be able to sue each other on a wide variety of claims (most of them apparently statecreated) under $\$ 302$ (e) of the Taft-Hartley Act. This would establish a further category of suits on state-created rights to which $\S 301(\mathrm{~b})$ should be applicable.

The dearth of inter-union litigation under $\S 301$, or elsewhere, should preclude the argument that federal courts will be flooded with litigation if such suits are not limited to contract cases. Cf. Association of Westinghouse Employees v. Westinghouse Corp., 348 U.S. 437, 460 (1955). Rather, under the view that in $\$ 301$ Congress made unions "newly created legal entities," International Ladies Garment Workers, AFL v. Jay-Ann Co., 228 F.2d 632, 635 (5th Cir. 1956), it seems very reasonable for Congress to provide that the occasional lawsuits between such entities may be heard in federal courts.

117. In the case of $\S 301$ (a) suits between employer and union, assuming that Congress intended to create some federal substantive right, there is no question that the right it had in mind was performance of collective bargaining agreements. Nor is it doubted that state rights would be enforced in 301 (a) suits in the absence of a showing of congressional intent to the contrary. See Association of Westinghouse Employees v. Westinghouse Corp., 348 U.S. 437 (1955); Note, 57 YALE L.J. 630 (1948); sources cited notes 92-94 supra. Since the legislative history of $\S 301$ (a) reveals no congressional intent to create federal rights as to relationships among unions, $\S 301$ (a) inter-union suits must be on state-created rights.

118. Section 303 suits enforce federal substantive rights. See International Longshoremen's Union v. Juneau Spruce Corp., 342 U.S. 237 (1952) ; Schatte v. International Alliance of Theatrical Stage Employees, 182 F.2d 158 (9th Cir.), cert. denied, 340 U.S. 827 (1950); Note, 59 Yale L.J. 575 (1950). 
limited to suits enforcing federal substantive rights, the suability provision of 301 (b) must have been intended to apply to some suits involving statecreated rights. Otherwise the provision would be redundant, since federal rule 17 (b) already permits suability of a union as an entity to enforce a federal substantive right. ${ }^{119}$

Under the view that 301 (b) has general applicability, its substantive character is even clearer. In this instance, regardless of how 301 (a) is interpreted, 301 (b) must govern suits in federal courts enforcing state substantive rights, e.g., in diversity jurisdiction. As shown above, 301(b) can not validly be applied in such cases unless it is deemed substantive law predicated upon the juridical person concept. ${ }^{120}$ And if 301 (b) is applied in diversity suits, arguments for a substantive interpretation of 301(b) based on the Erie and Angel rules are even more directly in point, since both cases were diversity proceedings. ${ }^{121}$

In enacting section 301, Congress intended to provide uniform means of enforcing collective bargaining contracts. ${ }^{122}$ Holding unions juridical persons as a matter of federal substantive law would fulfill this objective by binding state as well as federal courts. Unlike federal rules of procedure, federal substantive law supersedes conflicting state provisions by virtue of the supremacy clause of the Constitution. As has been seen, only by such supersession is 301 (b) valid. ${ }^{123}$ Thus state courts enforcing state-created rights (or of course federal rights) should be required to regard a union as a juridical person as they would any other federally-created juridical entity. Otherwise, where an action was cognizable either in federal courts under 301 (a) or in state courts, the choice of forum would determine not only the union's status in the litigation, but also whether the union had been a juridical person when the events giving rise to the litigation occurred. ${ }^{124}$ And where both diversity and 301 (a) jurisdiction requirements were met in the same case, ${ }^{125}$ two conflicting rules

119. In Association of Westinghouse Employees v. Westinghouse Corp., 348 U.S. 437, 454 (1955), the same argument was used to show $\$ 301$ (a) rights must be state-created.

120. See text at notes $98-102$.

121. See notes $100-01$ supra.

122. The Senate Committee report on 301 declared: "[U]ntil all jurisdictions, and particularly the Federal Government, authorize actions against labor unions as legal entities, there will not be the mutual responsibility necessary to vitalize collective bargaining agreements." S. Rep. No. 105, 80th Cong., 1st Sess. 17 (1947). See also id. at 15-18; H.R. REP. No. 245, 80th Cong., 1st Sess., $45-46$ (1947) ; Association of Westinghouse Employees v. Westinghouse Corp., 348 U.S. 437, 448 (1955); text at note 112 supra.

123. See text at note 102 supra.

124. E.g., in New York an agent's unratified act within the scope of his employment would have bound the union under $\$ 301(\mathrm{~b})$ but not state law. See note 163 infra. A similar situation would arise with $\S 303$ suits, which may be brought in federal or state courts. See note 111 supra.

125. E.g., United Elec. Workers v. Worthington Corp., 236 F.2d 364, 371 (1st Cir. 1956) ; Amalgamated Clothing Workers v. A. L. Kornman Co., 30 CCH Lab. Cas. $\llbracket 69952$ (M.D. Tenn., May 2, 1956) ; International Woodworkers v. McCloud River Lumber Co., 119 F. Supp. 475 (N.D. Cal. 1953) ; Isbrandtsen Co. v. Local 1291, International Long- 
of law would be applicable by the same federal court to the same operative facts. ${ }^{120}$ Apart from any Erie and supremacy clause considerations, a Congress seeking uniformity should not be deemed to have intended such inconsistent results. Rather the consistent outcome under supremacy clause doctrine points to both a reason for and a desirable result of interpreting 301 (b) as substantive law.

Finally, the Westinghouse interpretation of 301 makes the juridical personality concept indispensable if congressional objectives are to be met. Although Congress may have expected that employers primarily would benefit from the section, most 301 suits have been brought by unions against employers. ${ }^{127}$ Usually these actions have been maintained by unions to enforce members' claims; Westinghouse held, however, that 301 did not confer federal jurisdiction over such suits.128 Thus unions are thrown back on the state courts, whose previous failure to recognize them as juridical persons was the main reason for enacting $301 .{ }^{129}$ Construing the statute to overcome this nonrecognition would implement the congressional purpose despite Westinghouse. ${ }^{130}$

shoremen's Ass'n, 107 F. Supp. 72 (E.D. Pa. 1952), aff'd, 204 F.2d 495 (3d Cir. 1953) ; cf. Rock Drilling Union v. Mason \& Hanger Co., 217 F.2d 687 (2d Cir. 1954), cert. denied, 349 U.S. 915 (1955) (diversity but not $\$ 301$ jurisdiction). If unions are deemed "citizens" for diversity purposes, as suggested in text following note 172 infra, $\$ 301$ and diversity jurisdiction would frequently be available in the same suit.

126. E.g., in Local 205, United Elec. Workers v. General Elec. Co., 233 F.2d 85, 101-02 (1st Cir.), cert. granted, 352 U.S. $\$ 22$ (1956), the union was denied entity status necessary to maintain the suit in diversity while granted it to bring the suit under $\S 301$. Thus the union both was and was not an entity for the purpose of enforcing the same rights in the same action at the same time.

127. See Mendelsohn 169 n.9, 197 n.123 (citing figures); Wyle, Unions in Search of a Forum to Enforce Contracts, 7 LAB. L.J. 425, 427 (1956).

128. See Association of Westinghouse Employees v. Westinghouse Corp., 348 U.S. $437,459-61$ (1955); sources cited note 127 supra. Jurisdiction remains only for quaunion claims, not claims accrued to individual employees. But the line is not always easy to draw. See Mendelsohn 168 n.7, 196-97.

129. See notes 112 and 122 stipra.

130. The method of statutory construction suggested in this Comment renders unnecessary any express statutory language conferring entity status for all purposes. Were express provision required, however, it might be found in the $\$ 301(\mathrm{~b})$ clause authorizing a union to sue or be sued as an entity "in the courts of the United States." The quoted phrase might be read to include state courts. International Longshoremen's Union v. Juneau Spruce Corp., 342 U.S. 237, 240-43 (1952) is precedent for such a liberal interpretation. There a suit brought in the Alaska District Court was held within the $\S 303$ (b) authorization to sue "in any district conrt of the United States, subject to the limitations and provisions of section 301...." Usually "district court of the United States" is limited to courts established under Article III of the Constitution. But, the Supreme Court decided, "Congress was here [in $\S 301$ and 303] concerned with reshaping labor-management legal relations ....," and ". . . it is more consonant with the uniform, national policy of the Act" to include in its coverage the non-Article III Alaska District Court.

"That reading of the Act does not, to be sure, take the words 'district court of the United States' in their historic, technical sense. But literalness is no sure touchstone of lcgislative purpose. The purpose here is more closely approximated, 
Even if Congress had shared Justice Frankfurter's impression that the provisions of 301 were "procedural directions to the federal courts,"131 the substantive interpretation would be warranted to save the section's validity and purpose. ${ }^{132}$ Moreover, constitutional doubts about the jurisdictional grant of 301, which prompted the Westinghouse Court to interpret the section so narrowly, ${ }^{133}$ may be eliminated by construing the Taft-Hartley Act to create or confirm unions' juridical personality. There is little question that Congress may confer federal jurisdiction over entities created by federal law. ${ }^{134}$ And the plenary power over commerce should enable Congress to compel state as well as federal court recognition of juridical personality of all unions in an industry affecting commerce, ${ }^{135}$ or at least all those certified by the NLRB. ${ }^{138}$

we believe, by giving the historic phrase a looser, more liberal meaning in the special context of this legislation."

Id. at 243. The same policy warrants not restricting "the courts of the United States" in $\S 301$ (b) to courts established by the Constitution, i.e., federal courts. Since Innean Spruce extended "any district court of the United States" (as used in $\S \S 301$ (a) and 303) to cover all federal courts where suit might be brought, and $\S 301$ (b)'s language is broader - "the courts [not just the district courts] of the United States"- the latter phrase seems to refer to state courts as well. Moreover, although the last sentence of $\$ 301$ (b) refers to a "district court," the preceding reference to "courts of the United States" is not restricted to federal courts, and accordingly the broad interpretation of the latter phrase seems appropriate in the context.

131. Association of Westinghouse Employees v. Westinghouse Corp., 348 U.S. 437, 443 (1955).

132. Cf. id. at 453.

133. See id. at 459-61; Mendelsohn 168-69, 195.

134. See Osborn v. Bank of the United States, 22 U.S. (9 Wheat.) 737 (1824); Pacific R.R. Removal Cases, 115 U.S. 1 (1885); Puerto Rico v. Russell \& Co., $28 S$ U.S. 476, 485 (1933) ; Mishkin, The Federal "Question" in the District Courts, 53 Colur. L. REv. 157, 160-61, 187 (1953). But of. Association of Westinghouse Employees v. Westinghouse Corp., 348 U.S. 437, 450-51 (1955).

Section 301 (a) could be read as a statutory exception to 28 U.S.C. $\$ 1349$, which strictly limits jurisdiction over federally-created corporations. Or alternatively, it might be held there was no congressional intent to treat unions for purposes of $\S 1349$ as "corporation [s] . . . incorporated by or under an Act of Congress." Ibid.

Removal of doubts as to $\S 301$ 's constitutionality would not of itself enable the unionjuridical person to sue for employee claims. But once the constitutional question is removed, it is difficult to support Westinghouse's contrary holding in the face of the mandate of $\S 301(\mathrm{~b})$ : "[The union] may sue or be sued as an entity and in behalf of the employees whom it represents...." (Emphasis added.) See Mlendelsohn 194-201.

135. Section 301 covers: "Any labor organization which represents employees in an industry affecting commerce. ..." This is a much broader scope than the NLRB's jurisdictional standards have ever encompassed, and few unions would fall outside it. See, e.g., Shirley-Herman Co. v. International Hod Carriers Union, 182 F.2d 806, 808 (2d Cir. 1950).

136. Certification requires compliance with the filing requirements of $\$ \S 9(f)-(h)$, which resemble the registration requirements under the British Trade Union Act. Thus, limiting juridical person status to filing unions is analogous to Bonsor's limiting it to registered unions. See note 41 supra. But such a restriction seems unwarranted in American law, since the Supreme Court has held that the only consequence of noncompliance with 


\section{Inadequactes of the "Procedural" Approach}

The foregoing statutory basis for holding unions juridical persons as a matter of substantive law is further supported by the anomaly of the contrary view of union suability as "merely a procedural matter." This approach surrenders the possibility of uniformity, since Congress cannot establish procedural rules for state jurisdictions. ${ }^{137}$ Under the "procedural" view, a suit against a union in its common name differs only in convenience from the common law requirement of joining all members as defendants; the action is in effect a representative suit against the members. ${ }^{138}$ The rule that members of an unincorporated association are severally, not collectively, liable applies. ${ }^{139}$ Liability could only be collective if a new jural person had been created. ${ }^{140}$ But in practice a money judgment against a union almost always represents the imposition of just such collective liability. ${ }^{141}$ Because of the continually fluctuating membership which characterizes unions, the concept of a suit against the union as a representative action could rarely be accurate. At the time the suit is instituted the members will include some who did not belong when the cause of action accrued, and therefore should not share in liability or be represented in the suit; others who did belong then will have terminated membership and thus escaped liability. ${ }^{142}$

the filing requirements is loss of NLRB assistance, including right to certification. United Mine Workers v. Arkansas Oak Flooring Co., 351 U.S. 62, 73-4 (1956). See also Note, 66 Y YLE L.J. 771 (1957). Moreover, a noncomplying union may still sue under $\$ 301$. United Steelworkers v. Shakespeare Co., 84 F. Supp. 267 (W.D. Mich. 1949). On the other hand, conditioning juridical person status on obtaining certification accords better with the traditional idea that acquisition of corporate status depends on a voluntary act by the group. See Pullman Standard Car Mfg. Co. v. Local 2928, United Steelworkers, 152 F.2d 493, 497-99 (7th Cir. 1945) (dissenting opinion).

Since railway unions are covered by the Railway Labor Act, 44 STAT. 577 (1926), 45 U.S.C. $\$ \$ 151-\& S$ (1952), rather than the Taft-Hartley Act, the text discussion of statutory interpretation does not expressly apply to making them juridical persons. However, the Railway Labor Act, like the Wagner Act, was designed to encourage collective bargaining by unions. See, e.g., Railway Employes' Dep't, AFL v. Hanson, 351 U.S. 225, 233 (1956). Unions certified under it have in consequence frequently litigated as entities, and there seems no sound reason for denying them juridical personality possessed by other unions. In fact railway unions receive more favorable treatment than unions under TaftHartley, since the Railway Labor Act supersedes state "right to work" laws. Railway Employes' Dep't, AFL v. Hanson, stupra.

137. See notes 102 and 123 supra and accompanying text.

138. See Taff Vale Ry. v. Amalgamated Soc'y of Ry. Servants, [1901] A.C. 426, 438-40, 445; WARREN 666.

139. Sperry Products, Inc. v. Association of American Railroads, 132 F.2d 408, 410 (2d Cir. 1942), cert. denied, 319 U.S. 744 (1943); see note 12 supra; Comment, 32 Y ALE L.J. 59, 62 n.17 (1922).

140. Sperry Products, Inc. v. Association of American Railroads, supra note 139, at 410. See also Hart \& Wechsler, The Federal Courts and the Federal Systeng 965-66 (1953).

141. Section 301(b) expressly requires that liability be collective. And in Bonsor even the proponents of the "procedural" interpretation conceded that the union was liable "us an organized combination." [1956] A.C. 104, 145.

142. See note 42 supra and accompanying text. 
Under one suggestion, any member who had joined after the cause of action accrued should have his non-liability entered on the record and his contribution to the common property reserved in the judgment. ${ }^{143}$ Likewise, a member who had withdrawn after the cause of action accrued would remain liable from his private purse. ${ }^{144}$ Not only is the impracticability of such proposals manifest in the case of large unions; but it was to avoid just such complications that unions were made suable as entities in Coronado, Bonsor and the TaftHartley Act. Thus an attempted solution to the problem of union suabiiity that truly is "merely procedural" is virtually no solution at all. The practical solution of Coronado or Bonsor, however much it may be labeled "merely procedural,"145 in fact alters the incidence of liability from those who were members at the time of the actionable wrong to those who are members when the judgment is executed. ${ }^{146}$ Such shifting of liability makes sense only if predicated on an underlying concept of the union as a continuing substantive entity. ${ }^{147}$

\section{The Consequences of Juridical Personality}

The case law and statutory basis for holding unions juridical persons is supported by strong policy considerations. These derive from the procedural, substantive and diversity-jurisdiction consequences that would result.

\section{Procedure}

Recognition of unions as juridical persons would eliminate the procedural difficulties now attending suits involving unions. ${ }^{148}$ As has been noted, no American jurisdiction presently recognizes unincorporated unions as complete juridical persons; procedures for suing them ordinarily are assimilated to the procedures used for other unincorporated associations. ${ }^{140}$ The applicable federal rule, 17 (b), follows state procedure, except where a federal substantive right is involved..$^{150}$ State rules vary from statutory provisions for "common name" suits to the common law rule barring suits entirely. ${ }^{151}$ Other statutes

143. Sturges, Unincorporated Associations as Parties to Actions, 33 YaLE L.J. 383, 403 n.66 (1924).

144. Id. at 402 n.66.

145. See note 59 supra.

146. See Association of Westinghouse Employees v. Westinghouse Corp., 348 U.S. 437, 451 (1955) ; Lloyd, Damages for Wrongful Expulsion from a Trade Union: Bonsor v. Musicians' Union, 19 MODERN L. Rev. 121, 129 (1956).

147. See ibid.; cf. Warren 665-66; Voet, Comsarentary on the Pandects 541-42 (Gane ed., 1955). Likewise, the policy argument for holding the union liable emphasizes the union's character as an entity in fact. See United Mine Workers v. Coronado Coal Co., 259 U.S. 344, 383-89 (1922).

148. See Forkosch, The Legal Status and Suability of Labor Organizations, 28 TEMrP. L.Q. 1, 30 (1954).

149. See notes 8-18 supra and accompanying text.

150. See note 27 supra.

151. See Rock Drilling Union v. Mason \& Hanger Co., 217 F.2d 687, 691 (2d Cir. 1954), cert. denied, 349 U.S. 915 (1955) ; S. REP. No. 105, 80th Cong., 1st Sess. 15-17 
allow for some type of representative action by or against appropriate officers. ${ }^{152}$ But representative suits present difficulties, ${ }^{153}$ and even a successful plaintiff may be unable to reach the union funds..$^{154}$

No good reasons appear today for making the legal vindication of union rights and responsibilities subject to such vagaries of procedure. The historical opposition of union leaders to suability, which prompted many to regard Coronado as a great defeat for labor, ${ }^{155}$ may have been justified in a past generation. At that time unions generally faced an unsympathetic judiciary, lacked legal resources and had few important legal rights to enforce. ${ }^{156}$ If the harsh substantive law could not then be changed, ${ }^{157}$ unions might achieve practical immunity through procedural bars to suit. But the great increase in union strength and the acquisition of important legal rights requiring judicial enforcement has changed the unions' traditional attitude. ${ }^{158}$ Procedural bars are now more

(1947) ; Forkosch, The Legal Statils and Suability of Labor Organizations, 28 TEMr. L.Q. 1 (1954) (collecting statutes and cases).

152. See ibid.

Substantive entity status should preclude suits brought by or against officers as representatives of the union as it does in the case of corporations. Some who regard unions as entities for procedural purposes only, have nevertheless suggested that provision for common name suits bars representative actions, since the latter are meant as extraordinary remedies available only when joinder of an unreasonable number of parties would otherwise be necessary. See Sperry Products, Inc. v. Association of American Railroads, 132 F.2d 408, 411 (2d Cir. 1942), cert. denied, 319 U.S. 744 (1943); Comment, 33 Calif. L. Rev. 444, 446 (1945) ; 33 Colun. L. Rev. 363, 365 (1933). But see Walker v. Billingsley, [1952] 5 West. Weekly R. (n.s.) 363 (B.C. Sup. Ct.). The suggestion that $\$ 301$ (b) precludes representative suits involving unions in federal courts was made in Schatte v. International Alliance of Theatrical Stage Employees, 84 F. Supp. 669, 673 (S.D. Cal. 1949), but rejected in Tisa v. Potofsky, 90 F. Supp. 175, 180 (S.D.N.Y. 1950), followed in Copra v. Suro, 236 F.2d 107, 113 (1st Cir. 1956). But Tisa's basis meanwhile may have been vitiated by the same court's holding several weeks later, that $\$ 301(\mathrm{~b})$ has general applicability as a federal rule of procedure. Rock Drilling Únion v. Mason \& Hanger Co., 90 F. Supp. 539, 542 (S.D.N.Y. 1950).

153. See Bonsor v. Musicians' Union, [1956] A.C. 104, 144, 146; Citrine, Trade Union LaW 145-51, 456-60 (1950); Comment, 33 Calif. L. Rev. 444, 448 (1945).

154. Benz v. Compania Naviera Hidalgo, 233 F.2d 62 (9th Cir.), cert. denied on this issue, 352 U.S. 890 (1956) ; New York, N.H. \& H.R.R. v. Jenkins, 331 Mass. 720, 734-35, 122 N.E.2d 759, 767-68 (1954), rev'd on other grounds, 350 U.S. 155 (1956).

155. See Comment, 32 Yale L.J. 59, $63-64$ (1922). But see Frankfurter, The Coronado Case, 31 NEw REpublic 328 (1922) (labor would benefit from legal responsibility the Caronado decision established); Brandeis, The Incorporation of Labor Unions, 15 GREEN BAG 11 (1903) (similar argument).

156. See remarks of Samuel Gompers (1902), quoted in Roberts, Labor Unions, Corporations-The Coronado Case, 5 ILl. L.Q. 200-01 (1923); LIEBERMAN, UnIons BeF́ore THE BAR (1950).

157. Cf. Frankfurter, The Coronado Case, 31 NEw Republic 328, 330 (1922) (real problem is securing equitable substantive law on union responsibility).

158. See, e.g., remarks of AFL General Counsel, quoted in Busby v. Electric Utilities Employees Union, 147 F.2d 865, 867 (D.C. Cir. 1945) ; Comment, 32 YALE L.J. 59, 64 n.20 (1922). 
of a hindrance than a help. ${ }^{159}$ Desirable as it is that union-employer differences be settled by arbitration and negotiation rather than suit, ${ }^{100}$ the ultimate sanctions of the courts must be available to prevent these extra-legal adjustment processes from breaking down. Immunities from suit should arise not as procedural loopholes in legislative policy but only as its deliberate product, as in the case of the Norris-LaGuardia Act. ${ }^{161}$

\section{Substantive lawe}

The second major consequence of the juridical person concept would be to alter and enhance the privileges and responsibilities of unions and their members. Some new rights and obligations would be created and others now existing in theory would become enforceable in practice. Unions, like corporations, would be liable for their agents' acts as they already are for purposes of the Taft-Hartley Act. ${ }^{162}$ There would be an end to the "New York rule" under which the union incurs liability as an entity only on a showing that each member is liable, a condition almost impossible to meet. ${ }^{163}$ Likewise the union would acquire rights of action for injuries to it as an entity which would not have created liability to the individual members. Libel against the union is an example. ${ }^{164}$.

In the sphere of union-member relations, the nature of union membership rights and remedies would be clarified by the juridical person theory. ${ }^{105}$ Cur-

159. E.g., under $\$ 301$ of the Taft-Hartley Act the union is more often plaintiff than defendant. See notes 127 and 128 supra and accompanying text. On the other hand, in injunction cases, in which the union typically is defendant, lack of entity status does not impose procedural bars to suit, since equitable remedies have traditionally been available against unions through the class suit device. See note 12 supra.

160. See Shulman, Reason, Contract, and Law in Labor Relations, 68 HaRv. L. REv. 999 (1.955).

161. See, e.g., United States v. Hutcheson, 312 U.S. 219 (1941).

162. See 2 TELLER 70-75 (Supp. 1950).

However, juridical person status would not diminish the Norris-LaGuardia Act's limitations on vicarious liability. These apply equally to corporate and unincorporated bodies. See United Brotherhood of Carpenters v. United States, 330 U.S. 395 (1947).

163. Martin v. Curran, 303 N.Y. 276, 101 N.E.2d 683 (1951), 37 CoRNeLL L.Q. 814 (1952). But cf. People ex rel. Deverell v. Musical Mut. Protective Union, 118 N.Y. 101, 23 N.E. 129 (1889) (incorporated union held liable). See also S. REP. No. 105, 80th Cong., 1st Sess. 16 (1947) (extent to which "New York rule" followed).

164. Compare Kirkman v. Westchester Newspaper Inc., 287 N.Y. 373, 39 N.E.2d 919 (1942), and National Union of General and Municipal Workers v. Gillian, [1946] K.B. 81 (C.A.), with Formica v. McGraw-Hill Publishing Co., 19 L.R.R.M. 2029 (D.C. Ohio 1946).

165. Cf. Summers, Legal Linsitations on Union Discipline, 64 HARv. L. Rev. 1049, 1100 (1951) (basic need is not so much for greater limitations on union discipline as for a proper theory to rationalize them).

One remedy, damages for lost wages from wrongful expulsion, is now provided by the Taft-Hartley Act. Radio Officers' Union, AFL v. NLRB, 347 U.S. 17 (1954). This administrative remedy has been held to pre-empt the field, superseding state judicial remedies. Born v. Laube, 213 F.2d 407 (9th Cir.), rehearing denied, 214 F.2d 349 (9th Cir.), crrt. 
rent law governing these relations is a confused mixture of property-right, contract and status considerations. ${ }^{168}$ Conceptualizing these relations as rooted in contract between the union as a juridical person and the member would provide an adequate framework for determining the rights and remedies of each. ${ }^{107}$ And a union could avail itself of a provision in the membership contract granting it exclusive power to enforce members' claims under collective bargaining agreements ${ }^{168}$ - a result highly recommended by the realities of industrial life and a majority of the Supreme Court in Westinghouse. ${ }^{169}$ Were the union lax in enforcing such a claim, ${ }^{170}$ or otherwise remiss in its obligation to members, it should be suable as an entity in an action somewhat analogous to a stockholder's suit against his corporation. ${ }^{171}$

dcnicd, 348 U.S. 855 (1954) ; Mahoney v. Sailors' Union, 45 Wash. 2d 453, 460, 275 P.2d 440, 445 (1954), cert. denied, 349 U.S. 915 (1955) ; Real v. Curran, 285 App. Div. 552, 138 N.Y.S.2d 809 (1st Dep't 1955); see Isaacson, Labor Relations Law: Federal versus State Jurisdiction, 42 A.B.A.J. 415, 483 (1956). Contra, International Ass'n of Machinists v. Gonzales, 142 Cal. App. 2d 207, 217-21, 298 P.2d 92, 99-101 (1956), cert. granted, 77 Sup. Ct. 354 (1957) ; United Automobile Workers v. Hinz, 218 F.2d 664 (6th Cir. 1955).

166. E.g., Nissen v. International Brotherhood of Teamsters, 229 Iowa 1028, 1048, 295 N.W. 858, 869 (1941) (wrongful expulsion deprives member of property-right); Polin v. Kaplan, 257 N.Y. 277, 177 N.E. 833 (1931) (wrongful expulsion a breach of contract) ; Tunney v. Orchard, [1955] 15 West. Weekly R. (n.s.) 49, 75-77, [1955] 3 D.L.R. 15, 39-41 (Man. C.A.), 34 CAN. B. Rev. 70 (1956) (wrongful expulsion a tortious deprivation of status); Lucio v. Curran, 2 N.Y.2d 157, 162, 139 N.E.2d 133, 136 (1956) (same, semblc). See Summers, supra note 165, at 1050-58; Note, 41 Mins. L. Rev. 212 (1956).

167. Most American courts have avoided identifying who the parties to the membership contract are. See Summers, supra note 165, at 1055. The rationale of Kelly's case, see notes 34-36 supra and accompanying text, has not been followed in American wrongful expulsion suits, Annot., 62 A.L.R. 315, 316 (1929). But similar reasoning has been used to defeat other types of member claims. E.g., Marchitto v. Central R.R., 9 N.J. 456, 88 A.2d 851 (1952); Hromek v. Gemeinde, 238 Wis. 204, 298 N.W. 587 (1941).

168. See Textile Workers Union v. Textron, Inc., 99 N.H. 385, 111 A.2d 823 (1955).

169. 348 U.S. 437, 457-59, 465-67 (1955). See Mendelsohn 194-201; Stern, IntraUnion Activities, Membership and Collective Bargaining Rights under Pennsylvania Law, 29 TEMP. L.Q. 38, 57-64 (1955).

170. Cf. Rock Drilling Union v. Mason \& Hanger Co., 217 F.2d 687, 691 (2d Cir. 1954), cert. dentied, 349 U.S. 915 (1955) (union a trustee ad litem for members' claims).

171. See Witmer, Collective Labor Agreements in the Courts, 48 YALE L.J. 195, 238 (1938) (suggesting need to develop action against union equivalent to stockholder's suit in corporate law).

There should be analogies in union law to both the direct and derivative stockholder's suits. Thus, the former might be brought against the union if it refused to institute arbitration proceedings under the collective bargaining contract to enforce a member's rights. Doyle v. La Sorda, 135 N.Y.L.J. No. 87, p. 7, col. 6 (N.Y. Sup. Ct. May 3, 1956), and Terrell v. Local 758, International Ass'n of Machinists, 26 Lab. Arb. 579 (Cal. App. April $23,1956)$, illustrate the need for this type of suit. The action should also be available to restrain improper uses of union funds, such as those indicated in the recent congressional investigations of the Teamsters Union. See, e.g., Time, April 1, 1957, p. 14. The derivative suit might be brought by a number of members in the union's name, joining union and employer as defendants, if in a Westinghouse-type situation the union refused to sue the employer on the bargaining contract. 


\section{Diversity Jurisdiction}

Qualification of unions as "citizens" for purposes of federal diversity jurisdiction should be a further important result of the juridical person concept. The Supreme Court has never passed on the question of union "citizenship."172 Most lower federal courts, relying on the aggregate theory, have looked for diversity purposes to the citizenship of the members, as they would with any unincorporated association. ${ }^{173}$ But recently the Sixth Circuit, in American Federation of Musicians $v$. Stein, indicated that it might be prepared to consider a union a juridical person and hence a "citizen" were it proved to have the characteristics of the union described in Coronado. ${ }^{174}$

If the Supreme Court agrees that a union is a juridical person, the Court should likewise be willing to hold it a citizen for diversity purposes. In Puerto Rico v. Russell \& Co. ${ }^{175}$ the Court held that a Puerto Rican limited partnership (sociedad en comandita), a juridical person but not a corporation, was a citizen for diversity purposes. ${ }^{176}$ Citizenship, the Court made clear, is an attribute of juridical personality, not a consequence of incorporation or a "conclusive presumption" of the citizenship of shareholders. ${ }^{177}$ Since the leading

172. In Levering \& Garrigues Co. v. Morrin, 289 U.S. 103 (1933), certiorari was denied on the "citizenship" question although granted on another jurisdictional issue. Certiorari was also denied in Ex parte Edelstein, 279 U.S. 851 (1929) and in American Federation of Musicians v. Stein, 348 U.S. 873 (1954). In Barker Painting Co. v. Local 734, Brotherhood of Painters, 281 U.S. 462 (1930), diversity jurisdiction had been invoked on allegation that an unincorporated local union was a "citizen" (see Record, pp. 4, 18), but the Supreme Court opinion did not consider the point.

173. E.g., Hettenbaugh v. Airline Pilots Ass'n, 189 F.2d 319 (5th Cir. 1951) ; Levering \& Garrigues Co. v. Morrin, 61 F.2d 115 (2d Cir.), cert. denied on this issue, 287 U.S. 590 (1932) ; Ex parte Edelstein, 30 F.2d 636 (2d Cir.), cert. denied, 279 U.S. 851 (1929) ; cf. Russell v. Central Labor Union, 1 F.2d 412 (E.D. I1l. 1924) (same result under entity theory). But see Ex parte Edelstein, supra at 638-40 (dissenting opinion).

174. 213 F.2d 679, 685-88 (6th Cir.), cert. denied, 348 U.S. 873 (1954). Accord, Amalgamated Clothing Workers v. A. L. Kornman Co., 30 CCH Lab. Cas. I 69952 (M.D. Tenn. May 2, 1956). See Westinghouse Elec. Corp. v. United Elec. Workers, 92 'F. Supp. 841 (W.D. Pa. 1950) (requisite diversity between unions in interpleader action). See also Van Sant v. American Express Co., 169 F.2d 355, 372 (3d Cir. 1947) (joint stock company); Remington's Dairy v. Rutland Ry. Corp., 15 F.R.D. 488 (D. Vt. 1954) (partnership); Hansel v. Purnell, 1 F.2d 266 (6th Cir.), cert. denied, 266 U.S. 617 (1924) (voluntary association); cf. Seattle Brewing Co. v. Hansen, 144 Fed. 1011 (N.D. Cal. 1905).

175. 288 U.S. 476 (1933).

176. 3 MOORE 1413-14 approves the decision and recommends its extension to other unincorporated associations as a desirable change in existing law.

177. 288 U.S. at 479-80. The Court here enumerated five characteristics as establishing juridical personality. These are also possessed by unions. See the Supreme Court's description of union characteristics in United States v. White, 322 U.S. 694, 701-03 (1944), and the provisions of $\$ 301$. See also note 65 supra; cf. Hemphill v. Orloff 277 U.S. 537, 550 (1928).

A corporation was first deemed a citizen of the state of incorporation for diversity purposes in Louisville, C. \& C.R.R. v. Letson, 43 U.S. (2 How.) 497 (1844). The rule was later justified as a "conclusive presumption" that all the shareholders were citizens of the state of incorporation. Marshall v. Baltimore \& O.R.R., 57 U.S. (16 How.) 314, 329 (1854). See MrGovney, A Supreme Court Fiction, 56 HARv. L. Rev. 853 (1943). 
case against citizenship for unincorporated associations, Great Southern Hotel Co.v. Jones, rests on a stated unwillingness to extend the "conclusive presumption" rule to encompass partnership associations, ${ }^{178}$ it seems to have been in effect overruled by Puerto Rico. ${ }^{179}$ The Court itself, however, distinguished Great Southern and other precedents on the ground that suability was but one characteristic required for juridical personality and the associations involved in the earlier cases had lacked other necessary characteristics. ${ }^{180}$ Factually viewed, this distinction is tenuous and probably derives from the Great Southern Court's misunderstanding of the nature of the Pennsylvania limited partnership bringing the suit. ${ }^{181}$ Actually, the limited partnership in that case had virtually the same characteristics of juridical personality as the one in Puerto Rico. ${ }^{182}$ In the light of Puerto Rico, Great Southern seems to have validity, if at all, only on a point of pleading: the suit was brought not in the name of the association but of the partners, all of whom had the necessary diversity of citizenship but may have failed to allege it sufficiently. ${ }^{183}$ After amending the citizenship allegation they eventually won on the merits in the Supreme Court. ${ }^{184}$

178. 177 U.S. $449,457(1900)$.

179. See 33 Colum. L. Rev. 540, 541 (1933) ; 47 Harv. L. Rev. 135, 136 (1933).

180. Puerto Rico v. Russell \& Co., 288 U.S. 476, 480 (1933). Levering \& Garrigues Co. v. Morrin, 61 F.2d 115 (2d Cir. 1932), was among those found distinguishable; but the opinion shows the Court was under the erroneous impression that Levering involved a joint stock company, not a union. 388 U.S. at 480.

181. See W

182. The view that a Pennsylvania limited partnership has all the essential corporate characteristics had been expressed shortly before Great Southern by a circuit court on which sat future Chief Justice Taft and future Justice Lurton. Andrews Bros. Co. v. Youngstown Coke Co., 86 Fed. 585, 586-96 (6th Cir. 1898). Accord, Bushnell v. Park Bros. \& Co., 46 Fed. 209 (S.D.N.Y. 1891), aff'd, 60 Fed. 583 (2d Cir. 1894). Youngstozen, like Puerto Rico, concluded that these characteristics warranted diversity "citizenship." 86 Fed. at 595-96. This opinion, strikingly similar to Taft's in Coronado, may indicate how he would have resolved the union citizenship question had it been before him. See notes 64 and 65 supra.

Youngstowm, though rejected in Great Southern, contains a much fuller consideration than the latter of the nature of the Pennsylvania association. In Great Southern the Court was doubtless hindered by inadequate presentation by counsel. The Court first raised the citizenship question, not considered below, during the oral argument, and counsel then submitted memoranda on it. See 177 U.S. at 453. The short "Supplemental Memoranda" favoring citizenship, reprinted in Petition for Certiorari, pp. 91-93, Puerto Rico v. Russell \& Co., 288 U.S. 476 (1933), does not cite Youngstozm or other federal cases that support its position. Counsel probably was not much concerned over the citizenship point since the lack of diversity was curable by amendment. See notes 183-84 infra and accompanying text.

183. Even on this ground the decision would be questionable. Respondents pointed out in their Supplemental Memoranda, see note 182 supra, that their allegations implying all members were Pennsylvania citizens corresponded closely to allegations held sufficient as to plaintiffs' citizenship in Express Co. v. Kountze Bros., 75 U.S. (8 Wall.) 342, 351 (1869). But the Court in Great Southern misunderstood respondents as relying on Kountze's allegations of defendant's, not plaintiffs', citizenship, and on that basis rejected respondents' claim. 177 U.S. at 455.

184. Great Southern Hotel Co. v. Jones, 193 U.S. 532 (1904). 
Clearly, such a weak if often cited "leading case" should be given little weight in resolving the very different problems of union rights and responsibilities today. 185

In contrast to most uses of diversity jurisdiction today, extended diversity jurisdiction for unions ${ }^{186}$ would clearly implement the purpose underlying the constitutional provision: avoidance of local prejudice. The Framers sought to avoid both the possibility of prejudice in state tribunals and out-of-state suitors' fears on that account. ${ }^{187}$ Avoidance of hostile state legislation has also been suggested as their aim. ${ }^{188}$ All three reasons seem particularly applicable to union litigants in southern states, for example. Undoubtedly, unions there

185. Even weaker as a precedent is Chapman v. Barney, 129 U.S. 677 (1889), still cited frequently and held "decisive" of the citizenship issue in Great Southern Hotel Co. v. Jones, 177 U.S. 449, 454 (1900). In Chapman, as the Court itself pointed out, the citizenship question was not argued by either party. 129 U.S. at 681 . Nor was the plaintiff joint stock company even represented by counsel before the Supreme Court. Id. at 678. The Court cited no authorities and indicated no awareness of lower court precedents holding a joint stock company a citizen for diversity purposes. E.g., Baltimore \& O.R.R. v. Adams Express Co., 22 Fed. 404 (C.C. Md. 1884) ; Fargo v. Louisville, N.A. \& C. Ry., 6 Fed. 787 (C.C. Ind. 1881). Perhaps, as the language of Chapman implies, it too was simply a matter of bad pleading. See 129 U.S. at 682. It was so interpreted in Youngstozm, supra note 182, at 586, and perhaps by other lower courts that did not follow Chapman. See, e.g., Bushnell v. Park Bros. \& Co., 46 Fed. 209 (S.D.N.Y. 1891), aff'd, 60 Fed. 583 (2d Cir. 1894) (ignoring Chapman) ; cf. Johnson v. City of St. Louis, 172 Fed. 31, 40-41 (8th Cir. 1909) (distinguishing Chapman). Moreover, had the Chapman Court believed itself without jurisdiction, according to usual practice it would not have passed on the merits. See 129 U.S. at $680-81$.

Thomas v. Board of Trustees, 195 U.S. 207 (1904), holding citizenship of all members of the Ohio State University Board of Trustees must be alleged although the Board was suable in its own name, should be limited to its facts. There the Board was created by a special legislative act, which if construed to confer corporate powers would have violated the Ohio Constitution and overruled the state supreme court's interpretation of the Ohio statute. Moreover Thomas, like Great Southem, involved a relatively small association, all of whose members were citizens of the same state; they could feasibly be treated on an individual basis, as members of a large trade union cannot.

186. Unions now can qualify for diversity jurisdiction if, as occasionally happens, all individual members have the requisite citizenship. See cases cited note 125 supra. They also have qualified in class suits, where only the named representatives' citizenship is considered. E.g., Montgomery Ward \& Co. v. Langer, 168 F.2d 182 (Sth Cir. 1948); Tisa v. Potofsky, 90 F. Supp. 175 (S.D.N.Y. 1950); Local 192, American Federation of Teachers v. American Federation of Teachers, 44 F. Supp. 345 (E.D. Pa. 1942) ; see International Allied Printing Trades Ass'n v. Master Printers Union, 34 F. Supp. 178, 181 (D.N.J. 1940). But this circumvention of the usual diversity restrictions will be unavailable if $\S 301$ (b) has eliminated representative suits by union officials in federal courts. See note 152 supra.

187. Bank of United States v. Deveaux, 9 U.S. (5 Cranch.) 61, 87 (1809) (per Marshall, C.J.) ; Erie R.R. v. Tompkins, 304 U.S. 64, 74 (1938) ; Warren, New Light on the History of the Federal Judiciary Act of 1789, 37 HARV. L. REv. 49, 83 (1923).

188. Friendly, The Historic Basis of Diversity Jurisdiction, 41 HARv. L. Rev. 483, 495 (1928) ; Frankfurter, Distribution of Judicial Power Between United States and State Courts, 13 CORNELL L.Q. 499, 520 (1928). 
confront hostile state legislation ${ }^{189}$ and fear bias by state courts. ${ }^{190}$ A congressional subcommittee study showing the prevalence in the southeast of "abuse of injunctions" against unions indicates that such bias is real.191

Important additional reasons peculiar to the labor field exist for increased diversity jurisdiction. Labor law is an area in which most cases, even those concerning enforcement of state-created rights, will involve questions of federal law. A consistent and uniform solution of these federal issues can best be achieved by entrusting their treatment whenever possible to federal courts. In particular, extensive problems of pre-emption, more pronounced than in any other field, arise. The Supreme Court has emphasized that these preemption problems present complex questions susceptible of resolution only on a case-by-case basis through a long course of authoritative judicial decision. ${ }^{192}$ Yet in fact these difficult questions of federal law arise most often before a variety of lower state courts, which understandably lack the experience and qualification in labor law that federal district courts and the NLRB possess. ${ }^{193}$ And for the most part initial state court decisions granting temporary injunctions and denying the pre-emption claim finally dispose of the case at hand,

189. See, e.g., Saposs, Rebirth of the American Labor Movement, in Procespings of the Eighte Annual Meeting, Industrial Relations Research Ass'N 25 (1956); De Vyver, The Present Status of Labor Unions in the South-1948, 16 So. EcoN. J. 1, 16-17 (1949); Woll, Biased Against Labor, American Federationist, June 1956, p. 6; Rhodes, The South Moves Forward, id., May 1949, pp. 20-21; id., Feb. 1956, p. 39. The Supreme Court has invalidated some of the more extreme southern legislation. E.g., Hill v. Florida ex rel. Watson, 325 U.S. 538 (1945) ; Thomas v. Collins, 323 U.S. 516 (1945); Thornhill v. Alabama, 310 U.S. 88 (1940). "Right-to-work" laws present a serious obstacle to unionization in southern states. See sources cited supra. These have been held constitutional. Lincoln Federal Labor Union v. Northwestern Iron Co., 335 U.S. 525 (1949). But the Supreme Court has rebuffed their underlying philosophy: "One would have to be blind to history to assert that trade unionism did not enhance and strengthen the right to work." Railway Employes Dep't, AFL v. Hanson, 351 U.S. 225, 235 (1956).

190. See, e.g., Woll, supra note 189; American Federationist, Jan. 1956, p. 44.

191. Labor injunctions, the subcommittee found, have sharply increased in the southeast during the post-war period. They have been used by employers as economic weapons to exclude or defeat unions, thus frustrating the national policy of encouraging collective bargaining. In over $90 \%$ of the cases studied the employer-plaintiff was granted some relief; proceedings were usually $e x$ parte, with a hearing often delayed for weeks or months and seldom any higher court review. State Court Injunctions, Report of the Subcommittee on Labor-Management Relations of the Conmittee on Labor and Public Welfare, S. Doc. No. 7, 82d Cong., 1st Sess. (mislabeled 81st Cong., 2d Sess.) 6-12, 92-118 (1951). The report was compiled by independent university investigators.

192. E.g., Weber v. Anheuser-Busch, Inc., 348 U.S. 468, 480 (1955) ; Garner v. Teamsters Union, AFL, 346 U.S. 485, 500 (1953); Bethlehem Steel Co. v. New York State Labor Relations Bd., 330 U.S. 767, 771 (1947). See, generally, Hays, Federalism and the Taft-Hartley Act: A Constitutional Crisis in Procendngs, op. cit. supra note 189, at 56; Glushein, Federal Preemption in Labor Relations, 15 FED. B.J. 4 (1955); Cox, Federalism in the Law of Labor Relations, 67 HARv. L. REv. 1297 (1954).

193. See Hays, supra note 192, at 62; Rose, Federal-State Court Conflicts in Labor Injunction Cases, 15 FED. B.J. 16 (1955); Annot., 32 A.L.R.2d 1026 (1953) ; Annot., 97 L. Ed. 208,214 n.16 (1952). 
since generally the proceeding is either unreviewable or could not be reviewed in time to make any practical difference. ${ }^{194}$ Absent diversity, removal to a federal court can ordinarily be prevented by the employer wording his complaint solely in terms of state law. ${ }^{195}$ Nor can a federal court enjoin the state court's proceedings, however clearly the latter's jurisdiction may have been pre-empted. ${ }^{196}$ As a result, the national policy of labor relations is constantly being undercut by state courts. ${ }^{197}$ Diversity jurisdiction, when exercised originally or on removal, ${ }^{198}$ would enable the party so desiring to have cases

194. See sources cited note 193 supra; Sherman, State and Federal Jurisdiction in Labor Relations in Procendings, op. cit. supra note 189, at 71, 85 ; A state court temporary injunction is unreviewable by the Supreme Court, not being a "final order." Montgomery Bldg. Trades Council v. Ledbetter Erection Co., 344 U.S. 178 (1952).

195. See Gilbert, Removal and Remand under the Taft-Hartley Act, 7 LAB. L.J. 745 (1956) ; Comment, 52 MicH. L. Rev. 726 (1954).

196. Amalgamated Clothing Workers v. Richman Bros. Co., 348 U.S. 511 (1955), The Supreme Court, 1954 Term, 69 HARv. L. REv. 120, 180-85; NLRB v. Swift \& Co., 233 F.2d 226 (8th Cir. 1956), 41 MINN. L. Rev. 228. These decisions depend upon a stringent interpretation of the Judicial Code's limitations on the power of federal courts to enjoin state suits. 28 U.S.C. $\$ 2283$ (1952).

197. Congress deliberately chose not to allow private parties to obtain injunctive relief against conduct constituting unfair labor practices; the exclusive remedy was to be through the NLRB. See Amazon Cotton Mill Co. v. Textile Workers Union, 167 F.2d 183 (4th Cir. 1948) ; S. Rep. No. 105, 80th Cong., 1st Sess. 56 (1947); 93 Cong. Rec. 4132-33, 4834-47, 4864, 4868, 6446 (1947). Thus if state courts enjoin such conduct (and especially if they issue ext parte injunctions), the congressional scheme is circumvented. See Amalgamated Clothing Workers v. Richman Bros. Co., 348 U.S. 511, 524-26 (1955) (dissenting opinions); Isaacson, Labor Relations Lazw: Federal versus State Jurisdiction, 42 A.B.A.J. $415,484-86(1956)$. Likewise the congressional design is frustrated where state courts enjoin activity protected by federal law. E.g., United Mine Workers v. Arkansas Oak Flooring Co., 351 U.S. 62 (1956).

198. Removal of injunction cases presents special problems. First, the employer might join individual parties of local citizenship as defendants. See note 210 infra. But this should not be allowed to defeat removal if the union is a juridical person and a decree against it is sufficient to bind the members, see FED. R. Crv. P. 65(d), just as a corporation's right to remove cannot be thwarted by joining local stockholders as defendants. $C f$. Wecker v. National Enameling Co., 204 U.S. 176 (1907); Geer v. Mathieson Alkali Works, 190 U.S. 428 (1903) ; Boatner v. American Express Co., 122 Fed. 714 (C.C.W.D. Ky. 1903) ; Carothers v. McKinley Mining Co., 122 Fed. 305 (C.C.D. Nev. 1903). Individual defendants would not then be "parties in interest properly joined" as required to defeat removal by 28 U.S.C. $\$ 1441$ (b). Or if they were, the case against the union might be "a separate and independent claim or cause of action" meriting removal under 28 U.S.C. $\S 1441$ (c). Secondly, some federal district courts, when removal was sought on federal question grounds, have remanded state injunction cases on the ground that otherwise they would have to dismiss because the NLRB had exclusive jurisdiction or because the NorrisLaGuardia Act deprived them of jurisdiction to grant the relief requested. See sources cited note 195 supra. But neither reason seems adequate to deny the statutory right of removal on diversity grounds, 28 U.S.C. $\S 1441$. The federal court has jurisdiction in diversity to determine jurisdictional facts affecting the merits; if it then finds that the exclusive remedy is in the NLRB, its duty is to dismiss rather than remand to a state tribunal also having no jurisdiction. Nor should the Norris-LaGuardia Act prevent the 
that turn on federal labor questions decided in federal courts. ${ }^{199}$ In these tribunals, moreover, the provisions of the Norris-LaGuardia Act, applicable in diversity as in other cases, ${ }^{200}$ would effectively guard against abuses of the injunctive power. ${ }^{201}$

Congress in passing sections 301 and 303 of the Taft-Hartley Act deliberately chose to give federal courts jurisdiction over unions in matters previously cognizable only in state courts. Extension of diversity jurisdiction to unions is clearly consistent with this policy. ${ }^{202}$ But because the constitutional and

assumption of jurisdiction: the federal court may still grant the injunction if plaintiff meets the act's requirements, e.g., Tri-Plex Shoe Co. v. Cantor, 25 F. Supp. 996 (E.D. Pa. 1939), and the court is not restricted to giving injunctive relief but has jurisdiction to award damages instead. The most difficult problem might be determination of whether the $\$ 3000$ jurisdictional requirement was met. If removal is unavailable, the union might gain relief through an appropriate collateral action in federal court. For example, if it anticipates the employer's intention to seek a state court injunction against its federally-protected activities, it might enjoin the employer from instituting the suit. Cf. Ex parte Young, 209 U.S. 123 (1908) ; Looney v. Eastern Texas R.R., 247 U.S. 214 (1918). See also Texas \& N.O.R.R. v. Brotherhood of Ry. Clerks, 281 U.S. 548 (1930). Since state court proceedings would not have started, 28 U.S.C. $\$ 2283$ would not bar the injunction. See note 196 stpra and accompanying text. Or if the union suffered injury from an improperly granted state injunction, it might sue for damages in federal court. See Bunch v. Launius, 222 Ark. 760, 765, 262 S.W.2d 461, 464 (1953) (dictum).

199. In diversity jurisdiction, the Westinghouse limitations on union standing to enforce employee claims under the collective bargaining contract would not apply, since that decision dealt solely with $\S 301$ jurisdiction. See 348 U.S. at $459-61$. Rather the union could claim standing under FED. R. CIV. P. 17(a). It might qualify as "a party with whom or in whose name a contract has been made for the benefit of another"; or "trustee of an express trust"; or, if its membership contract so provided, an assignee for collection, which in most states would make it "the real party in interest." See 3 Moore 1312-72; AFL v. Western Union Tel. Co., 179 F.2d 535 (6th Cir. 1950) ( $\$ 301$ jurisdiction exists in suit brought by union involving violation of contract rights of one employee).

Should the still-outstanding question of whether $\S 301$ grants jurisdiction to enforce arbitration agreements be resolved in the negative, diversity jurisdiction might afford a forum for their enforcement. Bernhardt v. Polygraphic Co., 350 U.S. 198 (1956), only held the United States Arbitration Act inapplicable in diversity suits on contracts not involving interstate commerce. But collective bargaining contracts commonly involve interstate commerce and so, if otherwise within the act's coverage, may be enforceable in diversity situations. Cf. Krauss Bros. Lumber Co. v. Louis Bossert \& Sons, 62 F.2d 1004, 1006 (2d Cir. 1933). See, generally, Mendelsohn 172-75, 179-83; Cox, Grievance Arbitration in the Federal Courts, 67 HARv. L. REv. 591 (1954).

200. Lauf v. Shinner \& Co., 303 U.S. 323 (1938) ; Levering \& Garrigues Co. v. Morrin, 71 F.2d 284 (2d Cir. 1934); Tri-Plex Shoe Co. v. Cantor, 25 F. Supp. 996 (E.D. Pa. 1939). See Leiter Minerals, Inc. v. United States, 77 Sup. Ct. 287, 290 (1957) (dictum). Cf. Comment, 20 U. CHI. L. REv. 304 (1953).

201. See State Court Injunctions, op. cit. supra note 191, at 2-4.

202. Stevens, Corporations $\S 11$ (2d ed. 1949) points out that a policy of restricting federal jurisdiction has been behind denial of citizenship status to unincorporated associations. Therefore, Congress' decision to increase federal jurisdiction over unions should make the restrictive policy inapplicable to them. Cf. Frankfurter, The Distribution of Judicial Power Between United States and State Courts, 13 CoRnELl L.Q. 499, 506, 514 (1928) (specific policy considerations should govern extent of federal jurisdiction). 
statutory meaning of "citizens"203 is ultimately a question for the courts, 204 the step must be taken by them, as it was with corporations. ${ }^{205}$ Any restriction on the effects of such judicial interpretation should be left to Congress. ${ }^{200}$ In the face of sections 301 and 303 , it seems unlikely that Congress would choose to impose one. ${ }^{207}$

The availability of diversity jurisdiction should depend on the "citizenship" of the national or international union, not that of a local which may be involved in litigation. The constitution and conduct of the national union determine whether it will be held responsible and vicariously liable for the acts of the local in a given situation. ${ }^{208}$ But in any case it would be anomalous to give the local a different "citizenship," since the members of the local are also members of the national. ${ }^{209}$ To regard the local as having a different citizenship would often result in precluding diversity jurisdiction or removal, 210

203. U.S. CoNST. art. III, § 2; 28 U.S.C. $\$ 1332$ (1952).

204. See National Mut. Ins. Co. v. Tidewater Transfer Co., 337 U.S. 582 (1949); Hepburn and Dundas v. Ellzey, 6 U.S. (2 Cranch.) 445 (1804).

205. See note 177 supra; Hart \& Wechsler, The Federal Courts and tee Federal Systens 914-16 (1953). In the case of unions, unlike corporations, no overruling of earlier Supreme Court holdings is required. See note 172 supra and accompanying text.

206. See Burford v. Sun Oil Co., 319 U.S. 315, 344 (1943) (Frankfurter, J., dissenting) (it is up to Congress not Court whether to restrict diversity jurisdiction).

207. An argument that $\S 301$ would overburden the federal judiciary with a mass of petty litigation was made by opponents of that section. S. REP. No. 105, 80th Cong., 1st Sess., pt. 2, at 13-14 (1947) ; H.R. ReP. No. 245, 80th Cong., 1st Sess. 109 (1947) ; cf. Association of Westinghouse Employees v. Westinghouse Corp., 348 U.S. 437, 460 (1955). But Congress rejected the contention, and the minority's apprehensions have proved to be groundless since the number of $\$ 301$ suits litigated has averaged only about ten a year. See Mendelsohn 197 n.123; note 116 supra. The "burden" argument should be even less applicable to diversity jurisdiction for unions, since unlike $\S 301$ suits diversity suits are not exempt from the usual $\$ 3000$ jurisdictional requirement.

208. See, e.g., United Mine Workers v. Coronado Coal Co., 259 U.S. 344, 393-96 (1922) ; United Mine Workers v. Patton, 211 F.2d 742 (4th Cir.), cert. denied, 348 U.S. 824 (1954) ; Isbrandtsen Co. v. National Marine Engineers Ass'n, 9 F.R.D. 541 (S.D.N.Y. 1949); Gilbert, The International Union-A New Legal Entity, 7 LAB. L.J. 335 (1956). Cf. Stevens, Corporations $\$ 17$ (2d ed. 1949) (parent corporation sometimes held responsible for acts of subsidiary).

209. Moreover, the national ordinarily is responsible for organizing the local and for approving and partially financing those activities, such as strikes, which give rise to litigation. The local thus differs from a financially independent subsidiary corporation. See Brinker, Functions of National Unions as Contrasted with Their Locals, 16 So. EcoN. J. 23 (1949) ; Rose, Relationship of the Local Union to the International Organization, 38 VA. L. REv. 843 (1952), 4 LAB. L.J. 334 (1953); International Union of Operating Engineers v. J. A. Jones Constr. Co., 240 S.W.2d 49, 51 (Ky. 1951).

210. Were the local de'emed a citizen of the state in which it operated, there would be no diversity when an employer was from the same state, and no right of removal when a plaintiff employer was out-of-state. 28 U.S.C. $\$ \$ 1332,1441$ (b) (1952). A union local, however, does not owe its right to exist to state law, but to $\$ 7$ of the National Labor Relations Act. Accordingly, the status of an out-of-state national union's local affiliate should be analogous for jurisdictional purposes to that of an out-of-state corporation re- 
thus defeating the policy considerations for extending federal jurisdiction over unions. ${ }^{211}$ Since their juridical personality derives from federal legislation which requires identification of the principal place of business for registration and other purposes, ${ }^{212}$ unions should, like national banking associations, ${ }^{213}$ be deemed citizens for diversity purposes of the state in which their principal place of business is located. ${ }^{214}$

\section{CONCLUSION}

The concept of juridical personality is a legal tool employed in determining the relationship of a group to its own members and to third parties. Whether to assign the group various collective rights and responsibilities is initially a legislative question. But the conclusion that the legislature has conferred a status of juridical personality on a group may be inferred by the courts from

quired to incorporate locally: the out-of-state citizenship applies in determining diversity. Missouri Pac. Ry. v. Castle, 224 U.S. 541, 546 (1912) ; Southern Ry. v. Allison, 190 U.S. 326 (1903). See Hart \& WechSLER, op. cit. supra note 205, at 914; Note, 44 Harv. I. REv. 1106 (1931).

211. Should the policy considerations cease to be applicable as conditions change, Congress could contract the diversity jurisdiction, e.g., making it unavailable to local union plaintiffs.

212. Taft-Hartley Act, $\S \S 9(f)(1), 11(4), 301(c)$.

213. 28 U.S.C. $\$ 1348$ (1952).

214. Bankers Trust Co. v. Texas \& Pac. Ry., 241 U.S. 295, 309-10 (1916), holding a federal railway corporation not to be a citizen of any state for diversity purposes, involved a statute containing no implication relevant to citizenship of the corporation it created, and applied a deliberate congressional policy of restricting federal jurisdiction over railway corporations. But with unions, congressional policy is just the opposite. See note 202 supra and accompanying text. Therefore, although the legislative provision is less specific than 28 U.S.C. \& 134S, governing citizenship of national banks, union citizenship should follow the rule for national banks rather than that of Bankers Trust, supra. Whether the resulting "diversity" jurisdiction has its constitutional basis in the diversity or in the federal question grant of Article III, $\S 2$, or possibly in Article I powers, may be debatable. See Continental Nat'l Bank v. Buford, 191 U.S. 119 (1903) ; Ex parte Jones, 164 U.S. 691 (1897) ; Petri v. Commercial Nat'l Bank, 142 U.S. 644, 650 (1892) ; McGovney, A Silpreme Court Fiction II, 56 HARv. L. Rev. 1090, 1119-24 (1943). Cf. National Mut. Ins. Co. v. Tidewater Transfer Co., 337 U.S. 582 (1949). But the result is the same under any theory.

Those favoring treatment of unions as citizens for diversity purposes have suggested or assumed the state of citizenship would be that of the principal place of business. American Federation of Musicians v. Stein, 213 F.2d 679, 685 (6th Cir.), cert. denied, 348 U.S. 873 (1954) ; Amalgamated Clothing Workers v. A. L. Kornman Co., $30 \mathrm{CCH}$ Lab. Cas. I 69952 (M.D. Tenn. May 2, 1956) ; Ex parte Edelstein, 30 F.2d 636, 639-40 (2d Cir.) (dissenting opinion), cert. denied, 279 U.S. 851 (1929) ; 3 MOORE 1415-16. This suggestion seems more logical than the rule for corporations, whose citizenship and principal place of business often are in different states. A similar question arises in regard to unions registered under the British Trade Union Act. For jurisdictional purposes they are deemed citizens of the country (England, Scotland or Northern Ireland) where their principal office is located. Citrine, Trade Union Law 178-79, 246-47 (1950); Mackendrick v. National Union of Dock Labourers, [1911] Sess. Cas. 83, 89 (Ct. Sess. Scotiand). 
a pattern of legislative regulation. In Bonsor this reasoning was applied to determine that British trade unions are juridical persons.

In the United States, a far more extensive pattern of regulation creates correspondingly stronger reasons for holding unions juridical persons. The view that unions are mere aggregates of individuals is no longer consistent with the power they possess and the functions they exercise. Treating them as juridical persons would remove needless procedural difficulties and curtailment of substantive rights, and make diversity jurisdiction available to implement national labor policies. 